\title{
Pulvar River changes in the Pasargadae plain (Fars, Iran) during the Holocene and the consequences for water management in the first millennium BCE
}

\author{
Jean-Baptiste Rigot ${ }^{\mathrm{a},{ }^{*}, \text { Sébastien Gondet }}{ }^{\mathrm{b}}$, Marie-Laure Chambrade ${ }^{\mathrm{b}}$, Morteza Djamali ${ }^{\mathrm{c}}$, \\ Kourosh Mohammadkhani ${ }^{\mathrm{d}}$, Edit Thamó-Bozsó ${ }^{\mathrm{e}}$ \\ ${ }^{a}$ Université de Tours, CNRS, UMR 7324 Cités, Territoires, Environnements et Sociétés (CITERES), Tours, France \\ ${ }^{\mathrm{b}}$ Université Lyon 2, CNRS, UMR 5133 Archéorient, Maison de l'Orient et de la Méditerranée, Lyon, France \\ ${ }^{c}$ Aix-Marseille Université, CNRS, UMR 7263 Institut Méditerranéen de Biodiversité et d'Ecologie (IMBE), Aix-en-Provence, France \\ ${ }^{\mathrm{d}}$ University of Shahid Beheshti, Theheran, Iran \\ ${ }^{\mathrm{e}}$ Mining and Geological Survey of Hungary, Budapest, Hungary
}

\section{A R T I C L E I N F O}

Keywords:

Iran

Pasargadae

Holocene

Fluvial geomorphology

Hydraulic systems

Palaeo-environmental studies

\begin{abstract}
A B S T R A C T
Located in the middle basin of the Pulvar river (Fars, Iran), Pasargadae was founded around 550 BCE in the early days of the Achaemenid Empire. Its territory is dotted with remains of imposing hydraulic facilities (dams, dikes, canals), some of which date to that very period. The purposes and functions of these structures, built to exploit surface water, located in today's landscape (a deeply incised valley with temporary watercourses), raise questions and problems for which geomorphological studies provide major elements for consideration. Erosion of the Pleistocene glacis by the Pulvar and its tributaries caused several phases of alluvial deposition during the Holocene. They can be seen today in the Pasargadae region by examining the remains of three well-developed steplike terraces. These sedimentary units are primary archives for the reconstruction of river dynamics, and thus allow a better estimation of water availability. Since 2016, within the framework of a joint Iranian-French archaeological mission, several geo-archaeological campaigns have been carried out. Sediment analyses, C-14 dating and OSL dating of sediments collected in the alluvial formations, as well as in archaeological contexts, have been made to accurately reconstruct the variations over time in the Pulvar regime, as well as the past regional waterscape. From the beginning of the Holocene to the onset of the 1st millennium BCE, the Pulvar catchment area was marked by an aggradation phase, which led to the valley being filled with alluvial deposits. This sedimentary unit provided vast areas of arable land where cultivation could be enhanced by irrigation. The creation of water inlets in the Pulvar and its tributaries was at that time facilitated by riverbeds less incised than present-day ones. Ancient hydraulic systems reflect these geomorphological conditions, since they were built to manage higher water levels, as well as stronger flows, when compared to irrigation facilities developed in modern times.
\end{abstract}

\section{Introduction: humans and water in ancient Persia, a matter of landscape archaeology}

The territory of Persia corresponds to that of the present province of Fars in the centre-south of Iran and extends over the central part of the Zagros calcareous mountain range (Fig. 1a and b). It contains a dense hydrographic network, often consisting of endorheic watercourses, which progressively filled with alluvial sediments the bottoms of large synclines in the folded system of the Zagros. These basins constitute vast surfaces of arable land that are well watered and favourable to the development of agriculture.

This region of Iran was thus the cradle of numerous prehistoric cultures and then, in historical periods, of political entities that extended far beyond. Among these, the Achaemenid Empire (6th-4th centuries BCE) left a durable imprint with the foundation of the royal centres of Pasargadae, around $550 \mathrm{BCE}$, and then Persepolis, beginning in 520 $\mathrm{BCE}$. These sites, symbols of the power of kings, are also central places in charge of the enhancement of Persian territories (Henkelman, 2013,

\footnotetext{
* Corresponding author.

E-mail addresses: jb.rigot@univ-tours.fr, rigot@univ-tours.fr (J.-B. Rigot).
} 
2017). Until recently, research efforts were mainly concentrated on excavating the great sites of Fars. This resulted in scarce information being available on the occupation dynamics of the territories. However, in this region, the remains of numerous hydraulic systems, still poorly studied, are clear evidence for past exploitation of fertile basins via the development of irrigation. Their morphology can also inform on changes in the accessibility of water resources and the methods used to exploit them. Moreover, to analyse this waterscape, studies investigating Holocene geology remain rare for the region. In Fars province, quite few geomorphological studies on fluvial dynamics has been published (Nadji, 1997; Kehl et al., 2005, 2009; Kehl, 2009) while geo-archaeological studies related to human occupation are scarce (Helwing et al., 2010; Rigot, 2010; De Schacht et al., 2012).

Between 1999 and 2009 (and resuming in 2015), a pluri-disciplinary team participating in the joint Irano-French "Shiraz" research project concentrated on the study of Pasargadae by extending its field of investigation to the whole of the territory around this ancient city, namely, the plain of Pasargadae as well as adjacent valleys (Fig. 1c). Although the main aim is to better understand human occupation during the Achaemenid period, the project integrates a diachronic approach of the dynamics of population and the evolution of landscapes during the Holocene. In this framework, a pluri-disciplinary approach was set in motion to reconstruct the waterscape of the region. It is based on an archaeological methodology that integrates recording, dating and analysis of the remains of hydraulic structures. It is coupled with a regional geomorphological study centred on fluvial dynamics and the mechanisms of erosion-sedimentation between the interfluves and the fluvial systems.

From 2004 to 2006, an initial geo-archaeological study defined the frame of the major Holocene morphogenetic phases in a small part of the valley of the Pulvar hydro-system (Rigot, 2010). However, several questions remain relating to the chronology of morphogenetic phases and the mechanisms controlling the variability of sedimentary regime. Without viable data on the watershed scale the combination and comparison with the archaeological data were also incomplete. Since 2015, we have extended the breadth of our study to the entire Pulvar catchment area. The work thus presented in this article concerns four areas of geo-archaeological study: an upstream area (Shahidabad), two central areas (southern part of the Pasargadae plain and the valley of the Sarpaniran) and a downstream zone (gorges of the Tang-e Bolaghi) (Fig. 1c). The new data obtained during several field campaigns carried out between 2016 and 2018 have been coupled with the latest palaeo-environmental data, both at the regional and macro-regional level. We are thus able to propose a reconstruction of Holocene hydrographic conditions and hydraulic solutions set in place by human societies during the second half of the 1st millennium BCE.

\section{Regional setting}

\subsection{Ancient occupations and hydraulic remains}

The region of Pasargadae has been occupied by human populations
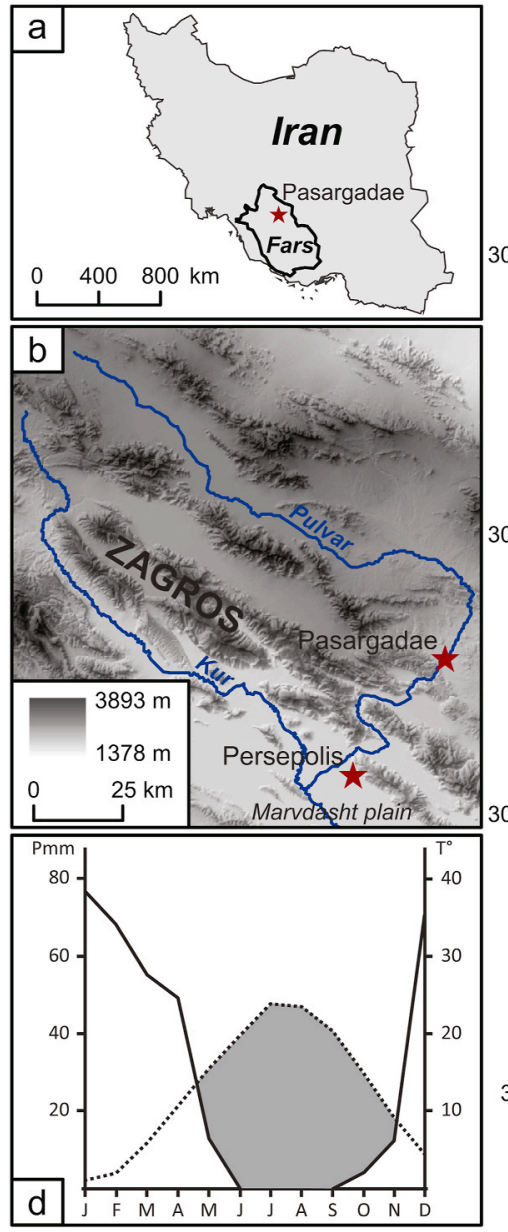

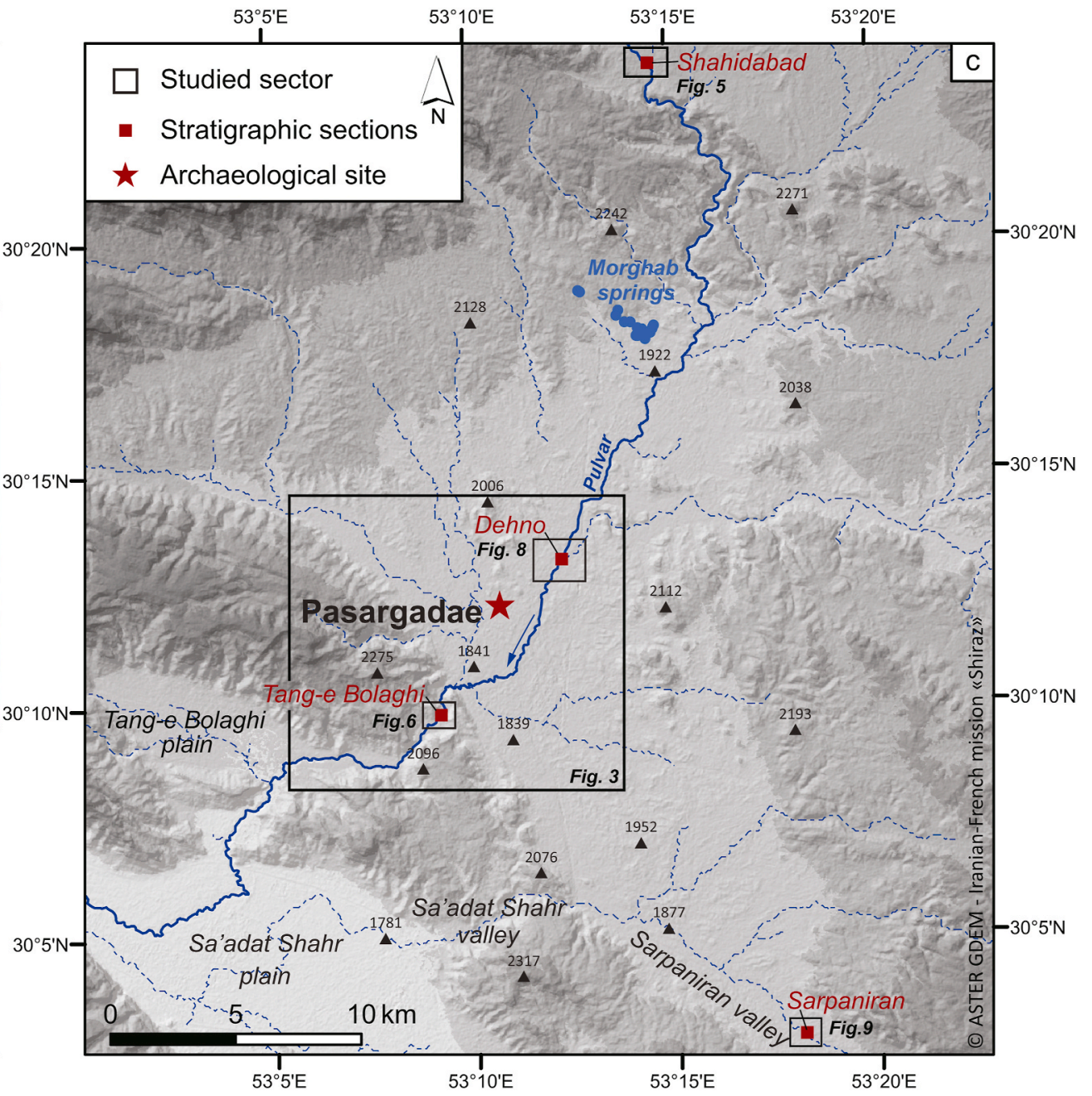

Fig. 1. a, b, c. Maps with location of the areas studied. d. Ombrothermic diagram of the Madar Soleiman station (Pasargadae) according to the averages of 25 years of precipitation readings (1983-2009) and 13 years of temperature readings (1996-2009). 
since at least the Epipalaeolithic (Tsuneki and Zeidi, 2008). The onset of agriculture in the region must have occurred at a very early date, as the remains of an aceramic Neolithic occupation (end of the 8th millennium - beginning of the 7th BCE) were recently discovered (Azizi Kharanaghi et al., 2014). While the Chalcolithic (5th millennium BCE) corresponds to a development of small farming communities (Helwing et al., 2010), the period of the Bronze Age (4th - 2nd millennium BCE), well recorded in the neighbouring region of Persepolis, is poorly represented around Pasargadae. The Iron Age (late 2nd - first half of the 1st millennium BCE) is practically absent in the region, as in the entire central Zagros. The Achaemenid period thus appears to have corresponded to a period of renewed occupation of this territory, highlighted by the foundation of Pasargadae. The later periods remain poorly studied but are very much present in the region. Pasargadae contains a series of large re-occupations that date from a period between the last third of the 1st millennium BC to the modern period (Stronach, 1978; Gondet et al., 2018a, 2018b). In the vicinity, a Sassanid site (3rd - 7th c. CE) was recently excavated (Asadi and Kaim, 2009) and many Islamic sites were recorded during recent surveys (Gondet et al., 2018a, 2018b).

The plain contains many remains of hydraulic structures, evidence for irrigated agriculture over time. In the north-west and west of Iran, the earliest traces of irrigation go back to the period of the NeolithicChalcolithic transition, namely between the end of the 6th and the first half of the 5th millennium BCE (Gillmore et al., 2011; Wilkinson et al., 2012; Vidale, 2018). However, in Fars, no hydraulic structure has so far been dated to before the 1st millennium BCE. Archaeological studies have focused on dams, dikes or elements of canals and dealt first of all with the plain of Persepolis. They showed that several of these are certainly Achaemenid (Nicol, 1970; Sumner, 1986; Boucharlat et al., 2012). Pasargadae has also long been the perfect illustration of the importance of water in this period. The excavations revealed the plan of a large royal garden based on a quadrangular network of stone canals (Stronach, 1978), associated with a vast body of water revealed later by geophysical survey (Benech et al., 2012). Around Pasargadae, hydraulic structures were also discovered and recorded during regional surveys (Kleiss, 1988, 1991, 1991; Yamauchi and Nishiyama, 2008). In 2008-2009, these structures were then studied in greater detail as part of the Iranian-French mission (De Schacht, 2018). Rescue excavations were undertaken on the dams of Shahidabad and Didegan, located upstream from the plain of Pasargadae. The C-14 dates obtained placed their construction at the beginning of the Achaemenid period (746-400 cal BCE for Shahidabad, 762-416 cal. BCE for Didegan, both dates being considered as terminus post quem). Moreover, this research led to the discovery of terracing works related to these constructions and intricate systems of flow control (De Schacht et al., 2012; Wilkinson et al., 2012). In parallel, remote sensing, combined with surveys in the field, enabled mapping of several undated irrigation networks on the plain, which require further study (De Schacht, 2018).

\subsection{Environmental setting and fluvial geomorphology}

The region is characterised by a semi-arid climate and is described as affected by a continental pluri-seasonal Mediterranean climate, according to the Global Bioclimatic Classification System (Djamali et al., 2011a). The annual average of precipitations is $336.6 \mathrm{~mm}$ (average over 25 years, Pasargadae station), centred on the winter period and the beginning of spring (Fig. 1d). The average annual temperature is $12.2^{\circ} \mathrm{C}$ (average over 13 years) with a maximum between the months of May and September. Frost is frequent, particularly in January and February, when the average temperature is $1.2{ }^{\circ} \mathrm{C}$. These conditions create a geomorphological dynamic typical of a mountain environment, marked by an intensity of erosion on the steep slopes and the production of an important volume of sediments affecting the hydrographic network.

The region of Pasargadae is situated in the folded structure of the Zagros range (Fig. 1b; Rigot, 2010; De Schacht et al., 2012). It is at the centre of an intermontane plain and is drained by the Pulvar. The 9000 $\mathrm{km}^{2}$ catchment area of the Pulvar is linked to that of the Kur in the plain of Marvdasht, to the south (Fig. 1b). The Pulvar is nowadays an intermittent watercourse that is regularly dry during the summer and autumn seasons. The rest of the hydrographic network also consists of non-perennial rivers. The catchment area is marked by the presence of intermontane plains of structural origin that follow each other from upstream to downstream (Fig. 1b). These morphological units are filled with fine sediments and surrounded by Cretaceous limestone mountains. Vast glacis from different generations stretch to the level of the alluvial floor. Portions of the watercourse cross the folds of the Zagros (which are oriented east-west), in a southerly direction, cutting these anticlines and forming gorges linking one plain to another (Fig. 1b).

Previous studies on the Holocene alluvial infilling of the Pulvar Valley (Rigot, 2010) have revealed the succession of three alluvial layers connected together, numbered T1, T2 and T3 from the earliest to the latest (Fig. 2). A first chronological proposal in the Pasargadae-Tang-e Bulaghi area was based on 3 radiocarbon dates from charcoal (Rigot, 2010). A particularly striking episode is the formation of $16 \mathrm{~m}$ thick layer T1 during the Early to Middle Holocene (one date of 7055-6652 cal. BCE, from a sample at a depth of $12 \mathrm{~m}$ ). This terrace can be seen all over the watershed of the Pulvar. The sediment is of very fine grain-size distribution, where silt is the dominant fraction (more than 60\%), which is unusual in a mountainous environment. The T2 layer is a less extensive deposit with a height of 6-7 m deposited during the Late Holocene (one date of 995-1156 cal. CE. obtained from a sample at a depth of 2.8 $\mathrm{m})$. It is characterised by a coarse level at the bottom and a fine, silty level at the top. It is present in the whole watershed. The T3 layer is a few meters high and made of coarse particles (one date of post-1650 cal. $\mathrm{CE}$ obtained at a depth of $0.8 \mathrm{~m}$ ) (Table 1 ). Of very small extension, it is visible in the entire watershed. The palaeo-environmental contexts and the chronology of these aggradation and incision events must still be better defined. We wish in particular to specify the end of the formation of $\mathrm{T} 1$ as well as its incision, which appears to have taken place during middle to recent Holocene. This scenario is, moreover, quite different from that proposed by other studies, which place T1 during the Pleistocene (Kehl et al., 2009; De Schacht et al., 2012; cf. 5.2). Yet the origin of the fillings, as well as the impact of humans on these fluvial dynamics, remain poorly understood.

\subsection{Changes in Holocene hydrology and vegetation in fars}

Over the last 15 years, the number of palaeo-environmental studies on lacustrine and wetland deposits in the Fars region has increased. These studies have provided records of the palaeo-hydrology and past vegetation, mostly covering the late Holocene (Djamali et al., 2009a, 2009b, 2015, 2018; Jones et al., 2015; Brisset et al., 2019). However, most of these studies have focused on lacustrine basins located further to the south/southwest of Fars province, with so far no palaeo-environmental records from the Pasargadae region itself. On a broader scale, high-resolution palaeo-environmental reconstructions are more numerous for the northern Zagros (Wasylikowa et al., 2008), northwestern Iran and eastern Anatolia (Sharifi et al., 2015), and southeast Iran (Hamzeh et al., 2016; Gurjazkaite et al., 2018; Vaezi et al., 2019; Safaierad et al., 2020). As regards these studies, the general postglacial hydro-climatic changes followed global trends, with glacial retreat and expansion of woodlands at the expense of open steppe landscapes. The continental inland region of Southwest Asia appears, however, as distinct from the temperate regions of Eurasia. The records demonstrate five millennia of delay in postglacial forest expansion in the former, while in the latter immediate forest expansion occurred at the onset of the Holocene (Wright et al., 2003; Djamali et al., 2010). This left continental Southwest Asia with a very seasonal climatic regime and an open landscape persisting until about 6.5 ka BP (Stevens et al., 2001, 2006; Djamali et al., 2010), which certainly affected the supply and transport of sediments in fluvial systems during the first half of the Holocene. 


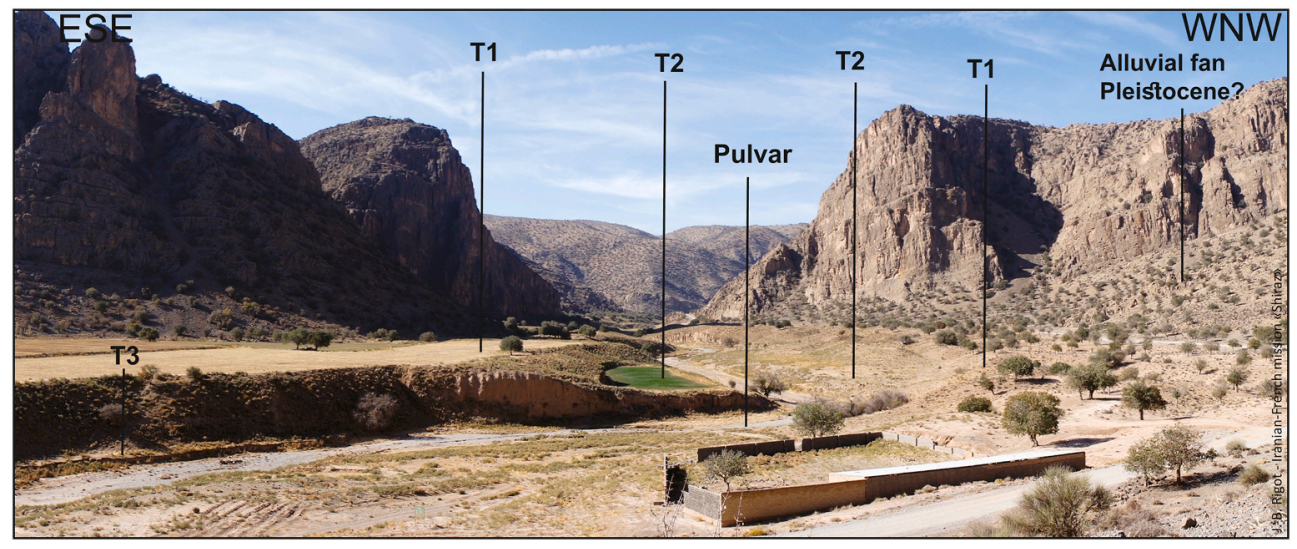

Fig. 2. Holocene fluvial forms in Tang-e Bulaghi.

Table 1

Radiocarbon dates.

\begin{tabular}{|c|c|c|c|c|c|c|}
\hline Sample ID & Lab. code & Radiocarbon Age (BP) & $\delta 13 \mathrm{C}(\%)$ & sample type & Calibrated ages & Deep \\
\hline P-E22/05 & Ly-3364 & $7945 \pm 50$ & no data & Charcoal & 7055-6652 BC & 12.00 \\
\hline TB-E26/05 & Ly-3365 & $990 \pm 35$ & no data & Charcoal & 995-1156 AD & 2.80 \\
\hline P-E16/05 & Ly-3363 & $140 \pm 30$ & no data & Charcoal & post $1650 \mathrm{AD}$ & 0.80 \\
\hline PAS17G-DH-04-06 & Ly-14808 & $1195 \pm 30$ & no data & Charcoal & 766-896 AD & 3.00 \\
\hline PAS17G-DH-04-05 & Ly-14809 & $1325 \pm 35$ & no data & Charcoal & 648-769 AD & 3.50 \\
\hline PAS18GEO-SS-10_2 & Poz-112109 & $330 \pm 30$ & no data & Charcoal & 1477-1643 AD & 0.35 \\
\hline PAS18GEO-SS-10_1 & Poz-111892 & $850 \pm 30$ & no data & Charcoal & 1152-1260 AD & 0.90 \\
\hline PAS18G-PP3-1-3 & Poz-111768 & $2415 \pm 30$ & no data & Charcoal & 746-401 BC & 1.30 \\
\hline
\end{tabular}

In the Fars region, the hydro-climatic reconstructions of two large lakes (Maharlou, $80 \mathrm{~km}$ south of Pasargadae, and Parishan, $150 \mathrm{~km}$ southwest of Pasargadae) not only reveal the high sensitivity of these hydro-systems to natural climatic variations in a semi-arid continental context, but also the significant modification of the hydrochemistry and the position of the water tables in their catchment basins as a result of human activities (Jones et al., 2015; Brisset et al., 2019). For both lakes, palynological investigations have shown a very prominent phase of human activity (observed for the Achaemenid period), with evidence of large-scale agro-pastoralism and, especially, the development of irrigated tree-farming (Djamali et al., 2015; Saeidi Ghavi Andam et al., 2020). Preliminary assessment of sediment cores in several wetland systems of the Persepolis basin and surrounding regions also show a very close human-wetland interaction, and the use of spring wetland water resources by humans at least since the Achaemenid period (Djamali et al., 2018). As regards the lack of palaeo-environmental records available from the Pasargadae region, the common hydro-climatic features of lake systems of Fars can be compared with the geomorphological phases mentioned in the present article.

\section{Material and methods}

To study the question of the interaction of human occupation with the hydrological dynamics in the plain of Pasargadae, we have merged the environmental and archaeological data, integrating the following: the study of the remains of hydraulic constructions; the characterisation of the fluvial geomorphological processes and combination with existing palaeo-environmental data; the dating of Holocene fluvial geomorphological events and archaeological remains by post-IR IRSL and C-14 dating of samples taken in natural and archaeological contexts.

\subsection{Archaeological study of the hydraulic structures}

The methods and tools used to analyse ancient hydraulic constructions in the region of Pasargadae have been described elsewhere
(Chambrade et al., 2020), and we shall present only a few reminders here. These methods and tools were adapted to specificities in the field, in particular the state of preservation of the remains, which led to the combination of several survey techniques: remote sensing based on aerial photographs and satellite images for general mapping (satellite images freely accessible on Google Earth and Microsoft Bing, SPOT and Pléiades images - ( ) CNES 2013 and Airbus DS 2018); systematic field survey of the remains (tablet with Oruxmaps application, GPS single-antenna Trimble Juno SB) complemented by precise topographic records in key sectors (GPS RTK Leica); absolute (OSL: post-IR IRSL) and relative dating (archaeological survey) of the remains. The projected system used for the whole mapping works of the project is UTM WGS 84 (Zone 39N).

Photo-interpretation work carried out for the study of the hydraulic landscape follows a common approach in Near Eastern archaeology (Wilkinson, 2003; Hammer, 2019). Like many arable sedimentary plains, the one of Pasargadae has over the last fifty years been subjected to an intensification of agricultural exploitation and considerable land consolidation related to mechanisation. From the point of view of landscape archaeology, it constitutes a zone of attrition (Wilkinson, 2003) in which the elements inherited from previous use of the land have mostly disappeared. We have thus based the study of the morphological dynamics of the irrigation systems on the interpretation of aerial photographs taken before the radical changes related to intensive mechanisation. We focused on a collection of aerial photographs in black and white, acquired from the Iranian National Cartographic Centre (INCC) in Tehran. They were taken at low altitude in 1966-67, before the extensive consolidation of agricultural lands, and have a resolution of between 0.6 and $3.5 \mathrm{~m}$. The goal was to detect the elements of ancient irrigation networks that have since disappeared. It also enabled mapping traditional irrigation networks in existence prior to the profound changes occurring over the last fifty years. Today, most of the irrigation water comes from underground water tables as result of the exponential development of motorised pumping.

This mapping was used as a base for studying the morphological 
dynamics of irrigation networks and detecting breaks and continuities between the ancient and the sub-present periods. This archaeomorphological approach was theorised in the field of archaeogeography (Chouquer and Watteaux, 2013; Orengo and Palet, 2016).

\subsection{Geomorphology}

The present geomorphological study is a multi-scalar approach of alluvial and colluvial units and sedimentary sequences in the upper and central watershed of the Pulvar, integrating observations previously collected in the lower watershed in the Persepolis plain. This approach allows us to compare morphological units at different scales and study their relation in terms of local and regional dynamics (transfer, storage, erosion), in association with human occupation and past environmental conditions. This approach has been regularly implemented in Mediterranean and arid environments (Fouache, 1999; Wilkinson, 1999; Lespez, 2007; Devillers, 2008; Purdue, 2013; Faust and Wolf, 2017). The work is the result of a combination of different techniques (Brown, 1999): a study of aerial photographs and satellite images; analysis of forms and deposits in the field and collection of samples; analyses in the laboratory. Fluvial processes are interpreted according to methods described in the important literature concerning dryland rivers (Graf, 1988; Tooth, 2000).

The geomorphological survey first concentrated on the plain and the Pulvar River, where geomorphological features are the most developed. A study of the tributaries and the whole catchment area was then conducted to map the large morphological units around the alluvial basin. In the field, the alluvial layers were mapped and placed. The formations were then studied in section thanks to the very strong incision of sedimentary deposits in the Pulvar. Each alluvial layer was closely examined, samples were taken in the various strata every $50 \mathrm{~cm}$ and recorded using a tacheometer (Leica) or a topographic GPS (RTK Leica). The samples were analysed in the laboratory (University of Tours, France) to characterize morphological units. The following analyses were conducted to assign them to a particular morphogenetic dynamic: grain-size analysis by laser particle sizer (micro-granulometer Mastersizer 3000); measurement of calcium content by decarbonation (Bernard calcimeter); measurement of organic content by weighing of organic matter before and after its destruction by hydrogen peroxide (H2O2). Concerning the organic content, the protocol is the following: the sample is weighted dry (precision of $0.1 \mathrm{mg}$ ), then the organic content is destroyed cold first, and secondly at $50^{\circ}$ (for lignins). Finally, the sample is bought to the boil to remove the remains of $\mathrm{H} 2 \mathrm{O} 2$ and reweighted dry to a precision of $0.1 \mathrm{mg}$.

\subsection{Absolute dating of geomorphological formations and archaeological remains}

Few Radiocarbon dates were obtained on charcoal using the AMS method. The very dry conditions are not favourable to the preservation of organic material. We thus concentrated on dating techniques via luminescence (OSL: post-IR IRSL). The OSL technique has been applied for more than 20 years in Iran for geomorphological studies, for example on the formations of loess in the country's north (Thomas et al., 1997; Wei et al., 2021), as well as on Zagros alluvial formations (Kehl et al., 2009; Rashidi et al., 2019). For deposits in archaeological contexts, it has been applied in different spatio-temporal contexts, for dating canals (Berger et al., 2009; Huckleberry et al., 2012) and sedimentary accumulations upstream from dams (Aiuvalasit et al., 2010). More specifically in Iran, it has been used to date excavated material from the digging of qanats (Fattahi, 2015; Bailiff et al., 2018) and the fills of canals (Gillmore et al., 2011).

Prior to the sampling campaigns, a sedimentary analysis carried out in 2016 on alluvial deposits sampled at Pasargadae confirmed the presence of quartz grains, and thus the possibility of applying the OSL technique. However, laboratory luminescence test measurements using
SAR-OSL protocol (Wintle and Murray, 2006) on coarse-grain quartz of two samples showed that these presented a bad recycling ratio and/or bad recuperation (Mining and Geological Survey of Hungary, Budapest, Ris $\varnothing$ TL/OSL DA-20 reader with a calibrated ${ }^{90} \mathrm{Sr} /{ }^{90} \mathrm{Y}$ beta source). The dating was therefore carried out on K-feldspar (mainly $0.10-0.16 \mathrm{~mm}$ grain-size, medium aliquots) by the post-IR IRSL at $290{ }^{\circ} \mathrm{C}$ SAR technique according to Thiel et al. (2011). Residual doses were measured after $4 \mathrm{~h}$ exposure to bright sunlight. The different tests yielded good results, and dose recovery ratios were also satisfactory. The age of deposition of the sediments with symmetric equivalent dose distribution was based on the mean $D_{e}$ values. The age of the samples which showed asymmetric $D_{e}$ distribution with some peaks, probably because of partially bleaching prior deposition, was calculated with the representative $\mathrm{D}_{\mathrm{e}}$ value determined by the Finite Mixture Model of Galbraith and Green (1990). In the case of one sample, it was calculated by the Minimum Age Model of Galbraith et al. (1999), which age models are usually used in larger $D_{e}$ data set. The ages are not fading-corrected because of the low fading rates measured by Auclair et al. (2003) on one or two feldspar separates from each location. Dose rates of the sediments were based on laboratory high-resolution gamma spectrometry measurements (Canberra) in the Institute for Nuclear Research, Hungarian Academy of Sciences (MTA Atomki).

Thirty samples were taken in the field in 2017, the majority from undisturbed contexts in various alluvial formations. In the T1 sedimentary sequence of Tang-e Bolaghi, (cf. 4.2.1.2), samples were taken every metre, in homogenous levels, mostly silty-sandy and sometimes sandy, using steel tubes $30 \mathrm{~cm}$ long and $5 \mathrm{~cm}$ in diameter pushed almost entirely into the sediment. Around them, samples were also taken to quantify the humidity and the dose rate. 13 samples were taken in the Tang-e Bolaghi area (PAS17-G-TB, Table 2). 4 samples were taken upstream in the T1 deposit of the Shahidabad area (PAS17-G-SA, Tables 2) and 2 samples in the T2 deposit of the Dehno area (PAS17-G-DH, Table 2). This sampling strategy reduces the risk of error by multiplying the dating. OSL dates are therefore used as a range for assessing the chronology of the sedimentation process.

In parallel, recent infrastructure-building and agricultural work have produced numerous stratigraphic sections in the archaeological vestiges of hydraulic constructions, favouring the taking of samples. In an ancient canal, Ju-i Dokhtar (cf. 4.1.1.1), we took three samples of sediment: two in the fill of the channel (PAS17-G-DK-01-01 and -02, Table 2) to date the process of infill after the abandonment of the canal, and one in the spoil bank obtained from the channel's excavation (PAS17-G-DK-02-01, Table 2), to date the digging and/or the cleaning of the canal. The date obtained for the latter sample will not be considered in this article. It is related to that of the Pleistocene deposits into which the canal was dug, showing that the feldspar minerals had not been exposed sufficiently to light during excavation work.

All the OSL dating are given in ka, i.e. the thousands of year before the date of sampling.

\section{Results}

\subsection{Archaeological and archaeo-morphological surveys of the hydraulic systems}

\subsubsection{Ancient hydraulic systems in the southern part of the plain of Pasargadae}

The remains of four hydraulic systems were surveyed in the downstream part of the plain of Pasargadae (Fig. 3): the Ju-i Dokhtar canal situated to the east of the southern part of the plain, the two networks of canals of the Tang-e Bolaghi in the south-west, and the canal of Abulvardi to the north-west of the site of Pasargadae. The last was subjected only to quick mapping in the field. Because data on it are rather scarce, we shall not describe it in detail below. 
Table 2

Post-IR IRSL dates. Ages calculated with estimated water content of the sediments.

\begin{tabular}{|c|c|c|c|c|c|c|c|c|c|c|c|c|c|c|c|c|c|c|c|c|c|c|c|c|c|}
\hline \multirow{2}{*}{$\begin{array}{l}\text { Sample } \\
\text { PAS17-G-TB-01-03 }\end{array}$} & \multirow{2}{*}{$\begin{array}{l}\text { Lab. } \\
\text { Nr. } \\
165.1 .\end{array}$} & \multirow{2}{*}{$\begin{array}{l}\text { Depth (m) } \\
13.18\end{array}$} & \multirow{2}{*}{$\begin{array}{l}\mathrm{n} \\
\mathrm{14}\end{array}$} & \multicolumn{4}{|c|}{ Equivalentdose(Gy) } & \multicolumn{3}{|c|}{$\begin{array}{l}\text { Residual dose (Gy) } \\
\text { mean }\end{array}$} & \multicolumn{3}{|c|}{$\begin{array}{l}\text { Residual subtracted } \\
\text { equivalentdose (Gy) }\end{array}$} & \multicolumn{3}{|c|}{ W.c.(\%) } & \multicolumn{3}{|c|}{ Dose rate $(\mathrm{Gy} / \mathrm{ka})$} & \multicolumn{3}{|c|}{$\begin{array}{l}\text { Post-IR IRSL290age } \\
\text { (ka) }\end{array}$} & \multicolumn{3}{|c|}{$\begin{array}{l}\text { Residual subtracted post- } \\
\text { IR IRSL290 } \\
\text { age (ka) }\end{array}$} \\
\hline & & & & 30.25 & \pm & 0.15 & FMM & 8.27 & \pm & 0.28 & 21.98 & \pm & 0.11 & 20 & \pm & 3 & 2.06 & \pm & 0.12 & 14.7 & \pm & 0.8 & 10.7 & \pm & 0.6 \\
\hline PAS17-G-TB-01-06 & 165.2 & 11.96 & 16 & 27.26 & \pm & 0.12 & FMM & 6.38 & \pm & 0.25 & 20.88 & \pm & 0.10 & 25 & \pm & 4 & 2.25 & \pm & 0.12 & 12.1 & \pm & 0.7 & 9.3 & \pm & 0.5 \\
\hline PAS17-G-TB-01-08 & 165.3 & 11.19 & 13 & 35.15 & \pm & 0.14 & FMM & 4.92 & \pm & 0.20 & 30.24 & \pm & 0.12 & 25 & \pm & 4 & 2.90 & \pm & 0.13 & 12.1 & \pm & 0.6 & 10.4 & \pm & 0.5 \\
\hline PAS17-G-TB-01-12 & 165.4 & 10.20 & 11 & 30.26 & \pm & 0.16 & FMM & 7.40 & \pm & 0.29 & 22.85 & \pm & 0.12 & 25 & \pm & 4 & 2.79 & \pm & 0.13 & 10.9 & \pm & 0.5 & 8.2 & \pm & 0.4 \\
\hline PAS17-G-TB-01-15 & 165.5 & 9.07 & 13 & 45.01 & \pm & 0.13 & FMM & 13.87 & \pm & 0.46 & 31.15 & \pm & 0.09 & 11 & \pm & 2 & 1.61 & \pm & 0.11 & 28.0 & \pm & 2.0 & 19.4 & \pm & 1.4 \\
\hline PAS17-G-TB-01-18 & 165.6. & 8.23 & 11 & 26.59 & \pm & 0.11 & FMM & 11.44 & \pm & 0.40 & 15.15 & \pm & 0.06 & 19 & \pm & 3 & 2.44 & \pm & 0.12 & 10.9 & \pm & 0.5 & 6.2 & \pm & 0.3 \\
\hline PAS17-G-TB-01-21 & 165.7 & 7.38 & 11 & 21.01 & \pm & 0.15 & FMM & 8.19 & \pm & 0.30 & 12.82 & \pm & 0.09 & 17 & \pm & 3 & 2.16 & \pm & 0.12 & 9.7 & \pm & 0.5 & 5.9 & \pm & 0.3 \\
\hline PAS17-G-TB-01-24 & 165.8 & 6.17 & 11 & 18.53 & \pm & 0.16 & FMM & 4.53 & \pm & 0.17 & 14.00 & \pm & 0.12 & 17 & \pm & 3 & 2.82 & \pm & 0.13 & 6.6 & \pm & 0.3 & 5.0 & \pm & 0.2 \\
\hline PAS17-G-TB-02-02 & 165.9. & 7.70 & 18 & 18.46 & \pm & 0.11 & FMM & 4.16 & \pm & 0.14 & 14.30 & \pm & 0.08 & 11 & \pm & 2 & 1.40 & \pm & 0.11 & 13.2 & \pm & 1.1 & 10.2 & \pm & 0.8 \\
\hline PAS17-G-TB-02-05 & 165.10 & 6.98 & 16 & 35.01 & \pm & 0.12 & FMM & 7.98 & \pm & 0.27 & 27.03 & \pm & 0.09 & 15 & \pm & 2 & 2.27 & \pm & 0.12 & 15.5 & \pm & 0.8 & 11.9 & \pm & 0.6 \\
\hline PAS17-G-TB-02-09 & 165.11. & 5.73 & 10 & 27.16 & \pm & 0.15 & FMM & 6.46 & \pm & 0.27 & 20.70 & \pm & 0.12 & 23 & \pm & 3 & 2.84 & \pm & 0.12 & 9.6 & \pm & 0.4 & 7.3 & \pm & 0.3 \\
\hline PAS17-G-TB-02-12 & 165.12 . & 4.82 & 8 & 29.41 & \pm & 0.18 & FMM & 4.87 & \pm & 0.16 & 24.54 & \pm & 0.15 & 20 & \pm & 3 & 2.83 & \pm & 0.13 & 10.4 & \pm & 0.5 & 8.7 & \pm & 0.4 \\
\hline PAS17-G-TB-02-15 & 165.13 & 3.96 & 10 & 24.52 & \pm & 0.17 & FMM & 4.62 & \pm & 0.16 & 19.90 & \pm & 0.14 & 17 & \pm & 3 & 2.69 & \pm & 0.12 & 9.1 & \pm & 0.4 & 7.4 & \pm & 0.3 \\
\hline PAS17-G-DH-04-07 & 165.14 & 2.38 & 7 & 4.26 & \pm & 0.34 & mean & 1.95 & \pm & 0.09 & 2.31 & \pm & 0.19 & 15 & \pm & 2 & 2.23 & \pm & 0.12 & 1.9 & \pm & 0.2 & 1.0 & \pm & 0.1 \\
\hline PAS17-G-DH-04-03 & 165.15 & 3.15 & 7 & 5.98 & \pm & 0.27 & mean & 1.74 & \pm & 0.08 & 4.24 & \pm & 0.19 & 18 & \pm & 3 & 2.61 & \pm & 0.12 & 2.3 & \pm & 0.2 & 1.6 & \pm & 0.1 \\
\hline PAS17-G-SA-01-12 & 165.17. & 1.70 & 10 & 13.52 & \pm & 0.16 & FMM & 2.49 & \pm & 0.13 & 11.02 & \pm & 0.13 & 22 & \pm & 3 & 3.21 & \pm & 0.13 & 4.2 & \pm & 0.2 & 3.4 & \pm & 0.1 \\
\hline PAS17-G-SA-01-08 & 165.18 & 3.62 & 9 & 14.37 & \pm & 0.14 & FMM & 3.98 & \pm & 0.16 & 10.39 & \pm & 0.10 & 15 & \pm & 2 & 2.40 & \pm & 0.12 & 6.0 & \pm & 0.3 & 4.3 & \pm & 0.2 \\
\hline PAS17-G-SA-01-04 & 165.19 & 5.42 & 8 & 13.71 & \pm & 0.17 & FMM & 3.30 & \pm & 0.20 & 10.41 & \pm & 0.13 & 12 & \pm & 2 & 2.40 & \pm & 0.12 & 5.7 & \pm & 0.3 & 4.3 & \pm & 0.2 \\
\hline PAS17-G-SA-01-01 & 165.20 & 6.88 & 8 & 20.24 & \pm & 2.08 & mean & 3.63 & \pm & 0.17 & 16.61 & \pm & 1.70 & 16 & \pm & 2 & 3.77 & \pm & 0.14 & 5.4 & \pm & 0.6 & 4.4 & \pm & 0.5 \\
\hline PAS17-PAL-06-01 & 166.1 & 2.12 & 9 & 12.27 & \pm & 0.53 & mean & 2.70 & \pm & 0.12 & 9.57 & \pm & 0.41 & 12 & \pm & 2 & 3.00 & \pm & 0.12 & 4.1 & \pm & 0.2 & 3.2 & \pm & 0.2 \\
\hline PAS17-G-DK-01-01 & 166.3. & 1.09 & 14 & 6.63 & \pm & 0.25 & FMM & 1.74 & \pm & 0.10 & 4.89 & \pm & 0.19 & 7 & \pm & 1 & 2.23 & \pm & 0.12 & 3.0 & \pm & 0.2 & 2.2 & \pm & 0.1 \\
\hline PAS17-G-DK-01-02 & 166.4 & 0.62 & 14 & 7.52 & \pm & 0.09 & FMM & 1.76 & \pm & 0.72 & 5.76 & \pm & 0.07 & 10 & \pm & 2 & 2.81 & \pm & 0.24 & 2.7 & \pm & 0.2 & 2.1 & \pm & 0.2 \\
\hline PAS17-G-DK-02-01 & 166.5. & 0.56 & 10 & 39.73 & \pm & 7.94 & MAM & 12.67 & \pm & 0.53 & 27.06 & \pm & 5.41 & 5 & \pm & 1 & 1.83 & \pm & 0.12 & 21.8 & \pm & 4.6 & 14.8 & \pm & 3.1 \\
\hline
\end{tabular}

$\mathrm{n}$ : number of aliquots.

FMM: representative equivalent dose according to the Finite Mixture Model of Galbraith and Green (1990),

MAM: representative equivalent dose according to the Minimum Age Model of Galbraith et al. (1999).

Mean: mean equivalent dose.

W.c.: water content. 


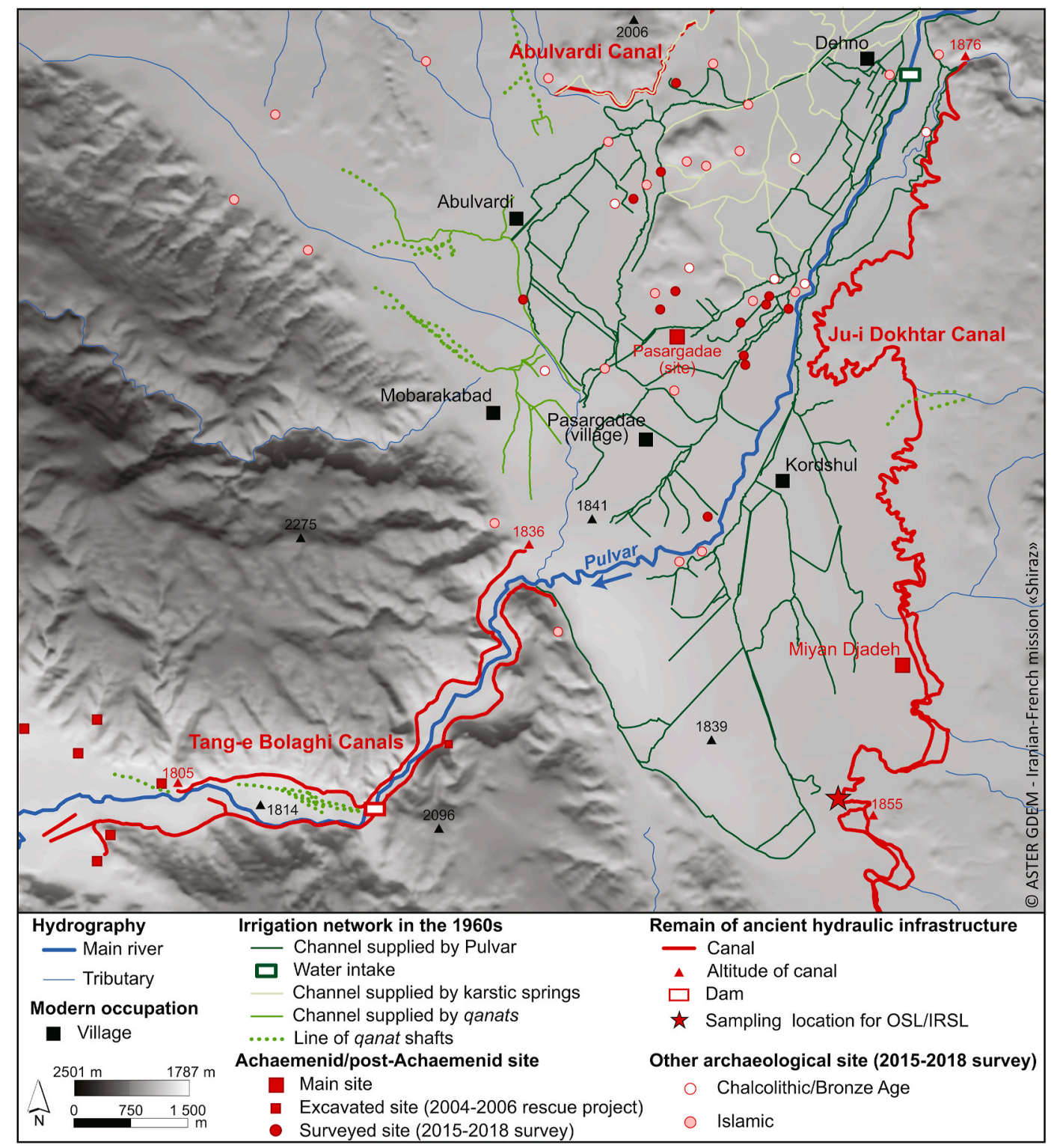

Fig. 3. Map of ancient hydraulic structures and sub-recent irrigation networks in the southern part of the Pasargadae plain.

4.1.1.1. Ju-i Dokhtar canal. In 2018, field operations were first concentrated on the Ju-i Dokhtar canal. They are detailed in a recently published article, with selected results summarized here (Chambrade et al., 2020). This canal runs $28.6 \mathrm{~km}$ north/south, following the relief of the glacis and dug into it (Fig. 4a). Its altitude lies between $1875.4 \mathrm{~m}$ and $1853.7 \mathrm{~m}$, i.e. between 13 and $35 \mathrm{~m}$ above the present-day elevation of the plain of Pasargadae, which on average is at $1840 \mathrm{~m}$ asl.

Its intake point is located at the exit of a steep-sided valley, the Tange Ganjak, located upstream from the site of Pasargadae, east of Dehno (Fig. 3). This valley receives the last section of a watercourse whose catchment area of $1208 \mathrm{~km}^{2}$ is one of the largest among those of the tributaries of the Pulvar. At the exit of this valley, the upper part of a weir was still visible on the land in the 1980s (Kleiss, 1991) as well as on the 1960s aerial photographs. Nowadays, this structure has been much destroyed. Its foundations are still visible only in section in the terraces, sealed in the alluvial sediments. This weir would have served to raise and conduct the water in the direction of the canal.

At mid-distance, the only known offtake of the canal was for the site of Miyan Jadeh located on the slope of the Pleistocene glacis (Fig. 3). Thanks to photo-interpretation, we have been able to map a complex of more than 85 ha containing buildings associated with probable large hydro-agricultural layouts. They are in the form of three blocks of several rectangular plots, each measuring hundreds of square metres. According to the aerial photographs, this system of plots could have continued downhill in the direction of the Pasargadae alluvial plain.

At the south-eastern extremity of the Pasargadae plain, the canal flows into the Sarpaniran valley, another tributary of the Pulvar, whose catchment area is smaller and located upstream from narrow gorges leading to the alluvial plain of Sa'adatshahr (Fig. 1c). Not far from the entrance to these gorges, a large dam about $500 \mathrm{~m}$ long was probably meant to store water coming from both this tributary and the Ju-i Dokhtar canal. The stored water would have been redistributed downstream to irrigate the extensive arable lands situated in the north-east of the Sa'adatshahr plain, less endowed with water resources.

The two post-IR IRSL dates of the infilling of the channel, carried out on samples taken $50 \mathrm{~cm}$ above one another, are very close. They permit placing the abandonment of the canal between $2.2 \pm 0.1 \mathrm{ka}$ (PAS17-GDK-01-01, Table 2) and $2.1 \pm 0.2 \mathrm{ka}$ (PAS17-G-DK-01-02, Table 2), that is during the last third of the 1st millennium BCE.

4.1.1.2. Canals in the valley of the Tang-e Bolaghi. In the gorges and 

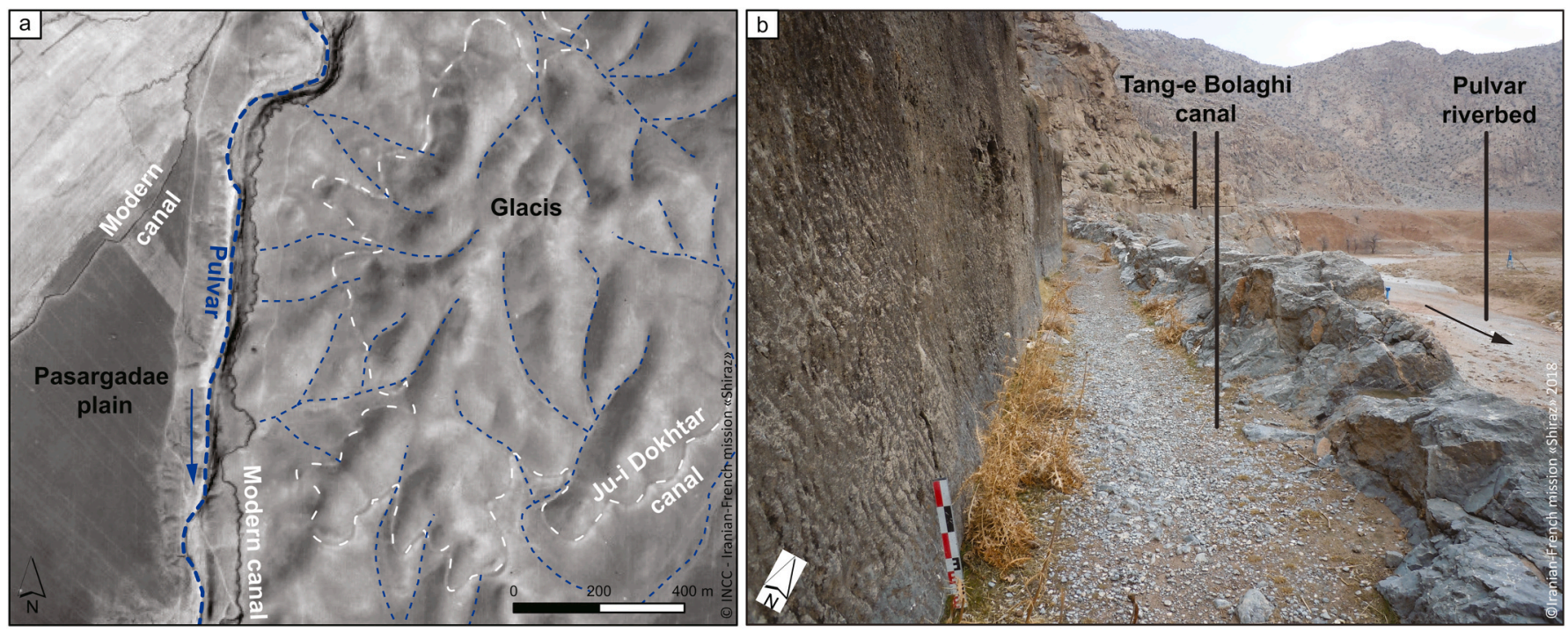

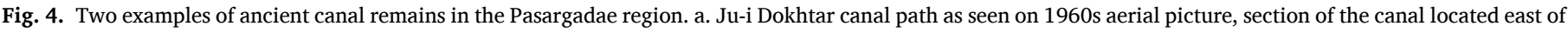
the site of Pasargadae; b. Tang-e Bolaghi canal, located in a valley further south of the Pasargadae plain, view of a rock-cut part on the right bank.

alluvial valley of Tang-e Bolaghi, two water canals are located on either side of the Pulvar. Partly studied during rescue excavation campaigns carried out between 2004 and 2006 (Atai and Boucharlat, 2009), a complete survey of their remains was carried out during the 2018 and 2019 campaigns, and several samples for OSL dating were then taken. These data are still being processed, but we can describe their general morphology and provide some elements of chronology.

On the left bank, the trace of a main canal and several derivations were detected over $9.3 \mathrm{~km}$. On the right bank, the canal has the form of a single channel running for a length of $9 \mathrm{~km}$ long. When mapping the two canals, we noticed they were meant to irrigate the small alluvial basin downstream from the gorges of the Tang-e Bolaghi. Upstream, the water intakes were not precisely located. The start of the canal on the right bank is certainly to be located in the western tributary of the Pulvar, which joins it at the entrance to the gorges, while the intake of the left bank canal remains unidentified. At the level of their farthest known point upstream, the two canals are situated at an altitude of about $1840 \mathrm{~m}$ asl, i.e. approximately $20 \mathrm{~m}$ above the present bed of the Pulvar.

Unlike the Ju-i Dokhtar canal, the channels of the two canals in the Tang-e Bolaghi were not dug but built. The channels, i.e. the ducts conducting water, have completely disappeared. No traces of hydraulic mortar or pieces of duct were found in the field. Their foundation structures are, however, still visible today. On pediments or alluvial terraces, they are linear features built with a double row of limestone blocks several decimetres in size. The channels may have run on top of these constructions. On the limestone outcrops, the water channels passed through rock-cut trenches (Fig. 4b). These construction characteristics are similar for the two canals, and could demonstrate that they were constructed at the same time.

As regards dating evidence for the two canals, only relative chronological data was available. On the right bank, several tombs under mounds of blocks were constructed right on the linear double row of stones defining the canal's foundation. Consequently, they osbtructed the canal, and were built after its abandonment. Thus, the tombs provide a terminus ante quem for the functioning period of the canals. The dating of this type of tomb remains poorly known, since most in the Pasargadae region have been looted. However, artefacts from an old excavation of one of these tombs in the Tang-e Bolaghi valley (Stronach, 1978), and recent C-14 dating on human bones recovered in the looted funerary chambers of several tombs of similar type located next to Pasargadae (Gondet et al., 2021), have permitted dating these burials to the first half of the 1st millennium CE. It is therefore certain that the canals of the Tang-e Bolaghi valley were no longer in use in this period. In addition, the rescue excavations conducted between 2004 and 2006, prior to the construction of a water dam downstream, have demonstrated that the valley was rather densely occupied during the Achaemenid/post-Achaemenid period (Adachi, 2008; Boucharlat, 2014; Askari Chaverdi and Callieri, 2016; Askari Chaverdi, 2018; Helwing and Seyedin, 2018). This was followed by a period of decline lasting at least until the Sassanid period (3rd-7th $c$. CE). Consequently, it may reasonably be inferred that these canals date to the second half of the 1st millennium BCE: they therefore match the valley's main period of occupation.

\subsubsection{Sub-present hydraulic systems}

The mapping of canal networks by looking at 'historical' aerial photographs enables one to better detail the workings of traditional irrigation in the early 1960s. In the southern part of the plain of Pasargadae, irrigation water transported via traditional systems comes mainly from the Pulvar. Outtakes located in the incised bed of the river raise the water to the level of the alluvial plain and feed the head canals. For example, on the right bank of the Pulvar, one of these begins east of Dehno village and follows a course of $2.5 \mathrm{~km}$, necessary in order to reach a height sufficient to irrigate arable land, where it divides into numerous secondary canals (Fig. 3).

The hydro-geological resources play a rather marginal role. Qanats, which in other regions of Iran are a major element of the hydraulic landscape (Manuel et al., 2018), are present, but are only part of small systems at the periphery of the plain. They mainly drain the underflows of two lateral dry valleys situated on the right bank. Archaeological surveys have shown that the vast glacis to the west of Pasargadae was only sparsely inhabited until the late Islamic period (Fig. 3), i.e. in the 16th $c$. CE at the earliest (Gondet et al., 2018b). Based on observations made on the map produced, the appearance of installations in this sector is related to the development, during this same period, of the systems of qanats.

The complex of karstic springs of Morghab (Fig. 1) is one of the major water resources for the region, providing water to the large northern half of the Pasargadae plain. The northern part of the study area constitutes the terminal section of the irrigation system fed by these springs, including a canal that in part follows the original line of the ancient, but undated, canal of Abulvardi (Fig. 3). 


\subsubsection{Archaeo-morphology of the hydraulic systems}

The implementation of the archaeo-morphological approach, i.e. the comparison between the ancient and sub-present irrigation networks' shape and location, must be approached with certain limitations in mind. First, between the dated archaeological structures and those detected through aerial photographs, two millennia have passed, for which we have very little data. The archaeological corpus of hydraulic structures must be considered fragmentary. However, comparison between the hydraulic systems does bring out specific characteristics for those preserved and dated to the second half of the 1st millennium BCE.

The canals south of the Pasargadae plain, both ancient and sub- present, are in their great majority fed by watercourses. It is interesting to note that the preserved parts of ancient systems are all situated very high on the foothills and the glacis which lie on the edge of the plain, while the sub-present canals mostly flow in the alluvial plain. For instance, along the eastern edge of the plain, the Ju-i Dokhtar canal lies on average more than $10 \mathrm{~m}$ above the later canal that brings water to the fields on the left bank of the Pulvar. Generally, ancient canals are located more than $20 \mathrm{~m}$ above the present base level of the river. In addition, the sub-present systems develop over quite short distances as the crow flies, and are no longer than $10 \mathrm{~km}$ from north to south, whereas the Ju-i Dokhtar system developed over a length of $15 \mathrm{~km}$.
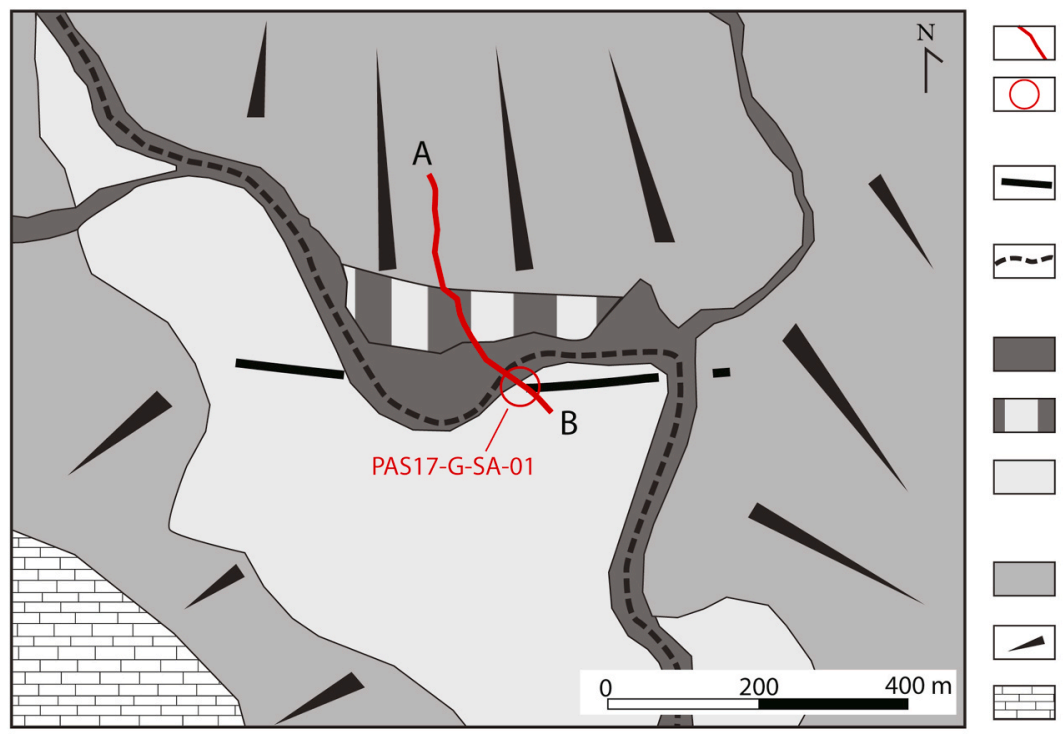

Sahidabad cross-section

Studied section

Remains of a earth levee

Pulvar river

Late Holocene

floodplain, T2 or T3 terraces

Holocene

$\mathrm{T} 2$ or eroded $\mathrm{T} 1$ terrace

Early to mid-Holocene

T1 terrace

Pleistocene (?)

Alluvial to colluvial deposits

Glacis, Pleistocene

Jurassic limestone

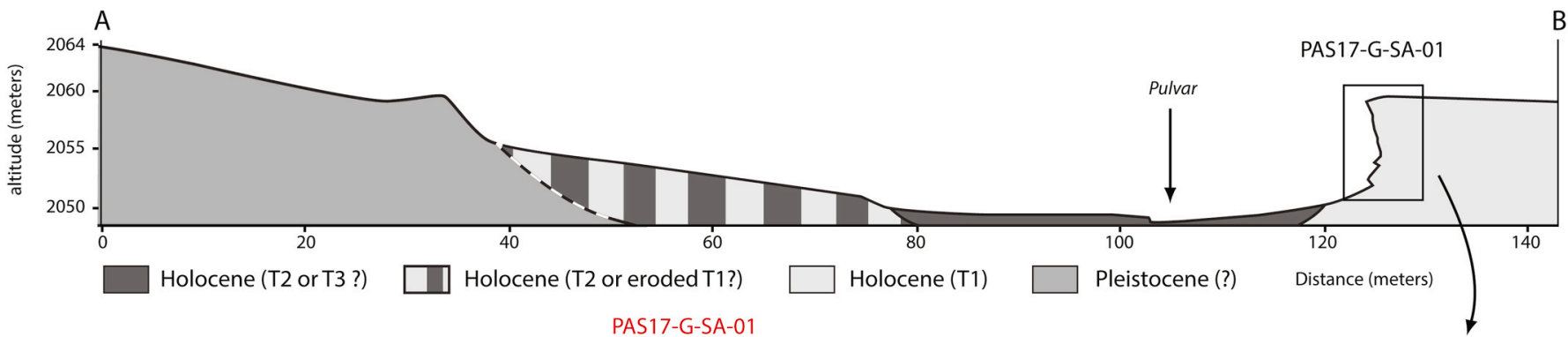
Silty-sandy carbonated deposit

2- Light brown indurated silts

3- Gravel, fine and coarse sands Bivalves, shells

4- Gravel, bivalves.

5- Light brown silts and fine sands.

6- Gravel, coarse sands, fine sands

lenses, bivalves, gasteropodes

7-Indurated greenish silty-sandy level

8- Greyish silts with brownish stains and blackish strata

9- Light brown silts with

few angular gravels

10- Not visible but probably similar

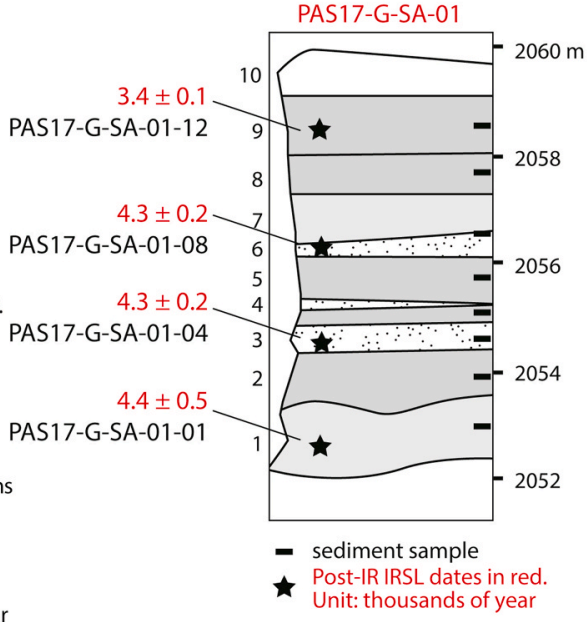

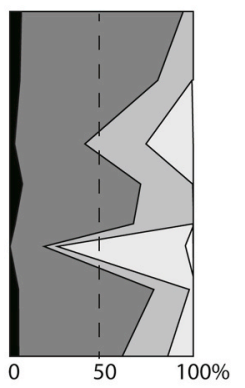

Clay
$\square \quad$ Silts
$\square \quad$ Fine sand
$\square \quad$ Medium and coarse sand

than 9

Fig. 5. Site of Shahidabad, Pulvar upper watershed: Pulvar valley profile, geomorphological units, study of the section (T1). 
Nevertheless, the Abulvardi canal is the only example whose systems show certain morphological continuity and where a sub-present canal is superimposed on the ancient one. The complex of the Morghab springs that fed these canals was certainly a more stable zone of water resources during the Holocene. The morphological differences thus concern above all the systems fed by fluvial waters, and our observations suggest, in contrast, greater stability of the systems fed from karstic springs.

\subsection{Geomorphological analyses of Holocene fluvial formations}

\subsubsection{Deposition and incision of $T 1$}

4.2.1.1. Stratigraphic section of Shahidabad. This section is situated upstream of the Pulvar's catchment area, a few hundred metres from the entrance to the gorges incising the anticlinal that dominates the plain of Pasargadae to the north (Fig. 1). The geomorphology of the neighbouring valley to the east, around the Achaemenid site of Didegan, has already been presented by De Schacht et al. (2012).

At this location, $\mathrm{T} 1$ lies about $10 \mathrm{~m}$ above the present riverbed (Fig. 5). It extends mainly on the right bank over several tens of hectares, right up to the limestone land formations. T2 and T3 can be seen fitted in T1. The terraces were established downstream from the extremity of a wide glacis whose genesis probably dates to the end of the Pleistocene. $\mathrm{T} 1$ is topped here by an artificial earth levee $700 \mathrm{~m}$ long. At its western extremity, the excavation of a structure for regulating flows has permitted dating this construction to the Achaemenid period (ibid.; De Schacht, 2018). The terrace and the levee were incised by a meander, which today allows the observation of the deposits in section.

Located $2 \mathrm{~m}$ above the bottom of the riverbed, the T1 section shows silty-sandy to silty levels nearly $2 \mathrm{~m}$ thick, then an assemblage of sandy to sandy-gravelled strata about $2.5 \mathrm{~m}$ in thickness, and finally again a silty stratum of about $3 \mathrm{~m}$ or more. On top, the remaining $1.5 \mathrm{~m}$ is not visible (Fig. 5). Sedimentary analyses show that most of the alluvial layer is silty-sandy, with large proportions of silts (from 50 to $90 \%$ towards the top of the section), and a very low proportion of coarse sands. Two strata are coarser with sands predominant (50-80\%). Calcimetric analyses show a large proportion of carbonates, $25-30 \%$ on average, up to $45-50 \%$ for the sandy strata. Finally, the proportion of organic matter is very low, between 1.8 and $2.8 \%$ at the top of the section, with lower proportions for the sandy strata $(0.6-0.9 \%)$. See Table 3 for detailed results.

Radiocarbon dates were obtained from charcoal, without clear results because of problems of remobilization of this material. However, four post-IR IRSL dates yielded interesting results. Three dates at $2.5 \mathrm{~m}$, $4.5 \mathrm{~m}$ and $6.5 \mathrm{~m}$ from the riverbed gave dates of $4.4 \pm 0.5 \mathrm{ka}, 4.3 \pm 0.2 \mathrm{ka}$ and $4.3 \pm 0.2 \mathrm{ka}$, respectively (Table 2 ). These dates are remarkably homogenous for a deposit $4.5 \mathrm{~m}$ thick. We can explain it by a problem of bleaching: as we took the samples in a sandy deposit of a palaeochannel, it is quite possible that these samples were not sufficiently exposed to light due to high sedimentation rate. In consequence, the dates we get must be older than they should and the gaps between them could be reduced or even eliminated. Moreover, the first date presents a margin of uncertainty of more than 500 years, which could push back the age of the base of the section. Finally, a fourth date at $8.5 \mathrm{~m}$ from the riverbed gave a result of $3.4 \pm 0.1$

4.2.1.2. Stratigraphic section of the valley of Tang-e Bolaghi. The valley of the Pulvar is here about $200 \mathrm{~m}$ wide and hemmed in by two steep slopes developed in the cretaceous limestone. The foot of the slopes is occupied by alluvial fans. The valley is filled with fine sedimentary deposits forming three terraces Rigot (2010) (cf. 2.2). The most ancient terrace (T1), $16-17 \mathrm{~m}$ above the actual channel, fills most of the valley.

Two sections situated $150 \mathrm{~m}$ from each other, representing the lower and the upper half of T1, were studied (Fig. 1; Fig.6). The first section presents, above $2 \mathrm{~m}$ that are not visible from the actual channel of the river, a remarkably homogenous deposit characterised by a silty sediment, $8 \mathrm{~m}$ thick. Noteworthy are several coarse strata in the middle part of the alluvial layer, which show the regular presence of small-scale palaeo-channels, showing an old level of the bedload. The second section, further upstream and nearer to the north slope, presents a deposit of the same type with a few sandy strata at the base, with a thickness of about $4.5 \mathrm{~m}$.

In the lower part of the first section, sedimentary analyses show that clays and fine silts are dominant (average of 50\%), then coarse silts (30\%). This proportion of fine particles diminishes slightly in the rest of the section. The variation in grain size is larger in the upper half of the first section and in the first half of the second section because of the presence of coarse strata. In these units, sands reach $40-50 \%$ of the total sediment, even $70-80 \%$ for coarse sands and stones in two samples. The calcium content, relatively regular, shows a large proportion of carbonates, with a percentage of about $35-40 \%$ in the whole of the sediment, and peaks of $65-70 \%$ in the palaeo-channels. There is thus a relation between the high proportion of carbonates and that of sands (Fig. 7). The examination of samples with a binocular microscope shows a high concentration of calcareous sandy particles. Finally, organic matter is present in low quantities, oscillating between 2 and $2.5 \%$ in the first half of the first section, up to 4 or $5 \%$ in the upper part of the first section and in the lower half of the second. The lowest percentages were observed in the channels (1.5-2\%). There is no sign of development of a palaeo-soil. See Table 4 for detailed results.

Post-IR IRSL dating was carried out for every meter along the two sections. The results, compared with the radiocarbon dates published in Rigot (2010), are relatively satisfying. Concerning the first section, the dates oscillate around $10 \mathrm{ka}$ between 3 and $5 \mathrm{~m}$ above the riverbed $(10.7$ $\pm 0.6 \mathrm{ka}$ at $3 \mathrm{~m}, 9.3 \pm 0.5 \mathrm{ka}$ at $4 \mathrm{~m}$ and $10.4 \pm 0.5 \mathrm{ka}$ at $5 \mathrm{~m}$ ) up to about 5 $\mathrm{ka}$ at $10 \mathrm{~m}$ (Table 2). For the second section, the dates range from $10.2 \pm$ $0.8 \mathrm{ka}$ at $8.4 \mathrm{~m}$ above the riverbed to $7.4 \pm 0.3 \mathrm{ka}$ at $12 \mathrm{~m}$. Here, we note age reversal between the upper part of $\mathrm{T} 1$ (section 2) and the lower part of $\mathrm{T} 1$ (section 1). When considering the two sections separately, three age reversals were noted.

\subsubsection{Deposition and incision of $T 2$}

4.2.2.1. Stratigraphic section of Dehno. This section lies in the centre of the alluvial plain (Fig. 1), $4 \mathrm{~km}$ north-east of Pasargadae, located a few tens of meters upstream from a now abandoned outtake still visible in the riverbed of the Pulvar. It used to feed a canal on the right bank of the Pulvar, which provided water to all the cultivated fields to the north and

Table 3

Results of grain size, carbonates and organic content analysis (\%). T1 terrace, Shahidabad section (PAS17-GSA-01).

\begin{tabular}{|c|c|c|c|c|c|c|c|c|c|}
\hline Sample code & $0-2 \mu \mathrm{m}$ & $2-20 \mu \mathrm{m}$ & $20-50 \mu \mathrm{m}$ & $50-200 \mu \mathrm{m}$ & $200-500 \mu \mathrm{m}$ & $500-2000 \mu \mathrm{m}$ & carbonates & Organic matter & Altitude (m) \\
\hline PAS 17 GSA 01_11 & 4.85 & 35.28 & 22.12 & 24.27 & 11.25 & 2.24 & 23.5 & 2.0 & 2058.3 \\
\hline PAS 17 GSA $01 \_10$ & 5.07 & 44.12 & 29.1 & 19.15 & 2.57 & 0.0004 & 26.0 & 2.8 & 2057.2 \\
\hline PAS 17 GSA 01_09 & 0.65 & 11.23 & 7.31 & 7.08 & 16.19 & 52.95 & 43.8 & 0.9 & 2056.6 \\
\hline PAS 17 GSA 01_07 & 3.23 & 31.22 & 32.83 & 32.35 & 0.36 & 0 & 30.9 & 1.5 & 2056 \\
\hline PAS 17 GSA 01_06 & 7.18 & 39.59 & 24.49 & 28.07 & 0.67 & 0 & 29.9 & 1.4 & 2055.1 \\
\hline PAS 17 GSA 01_05 & 3.11 & 24.88 & 13.17 & 33.06 & 24.82 & 0.96 & 53.8 & 0.6 & 2054.6 \\
\hline PAS 17 GSA 01_03 & 5.96 & 45.57 & 28.93 & 18.38 & 1.15 & 0 & 26.8 & 1.8 & 2054.1 \\
\hline PAS 17 GSA 01_02 & 6.19 & 60.76 & 26.83 & 6.22 & 0.0006 & 0 & 30.8 & 1.8 & 2053.1 \\
\hline
\end{tabular}



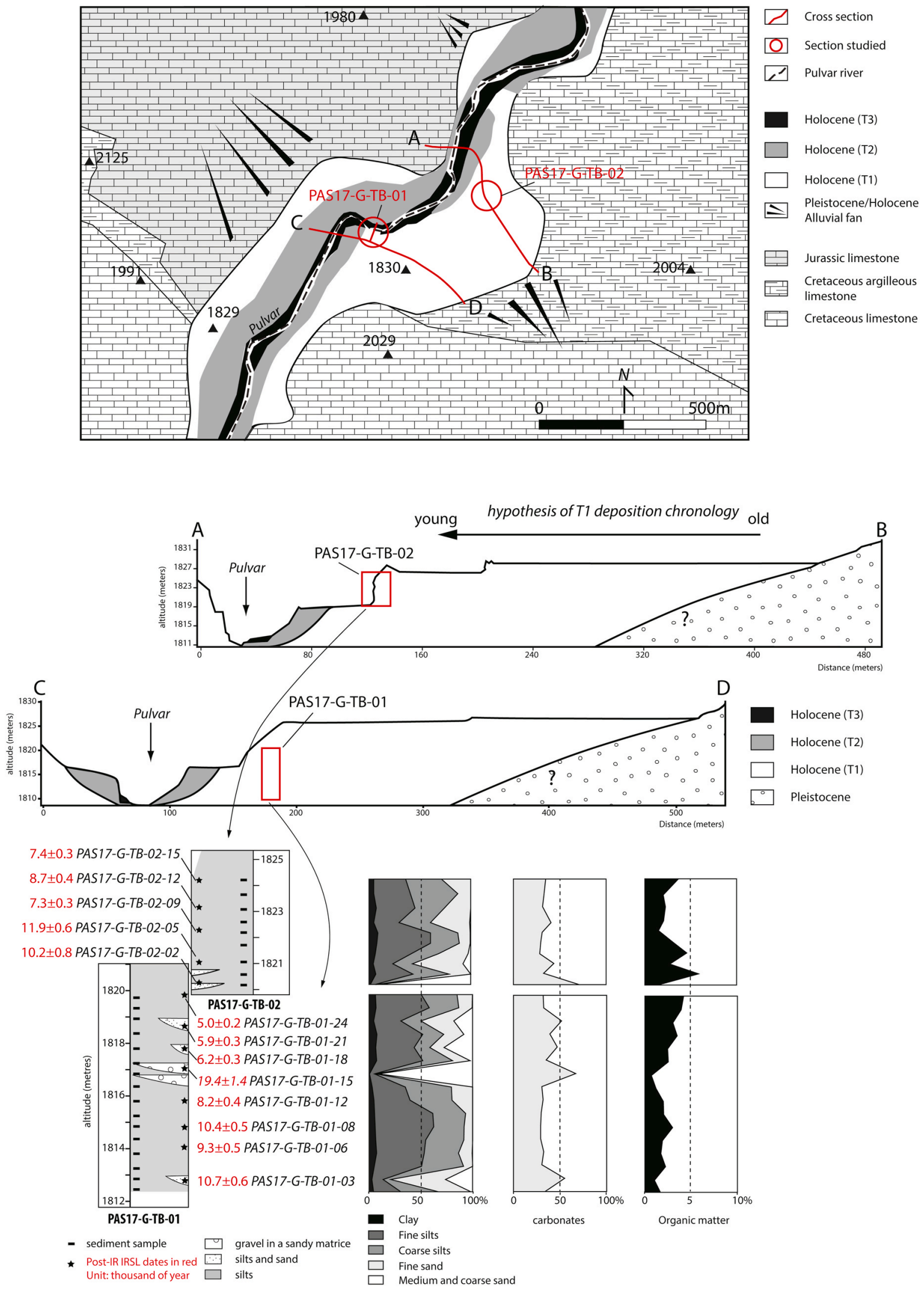

Fig. 6. Tang-e Bulaghi, centre of the Pulvar watershed: Pulvar valley profile, geomorphological units, study of sections (T1). 


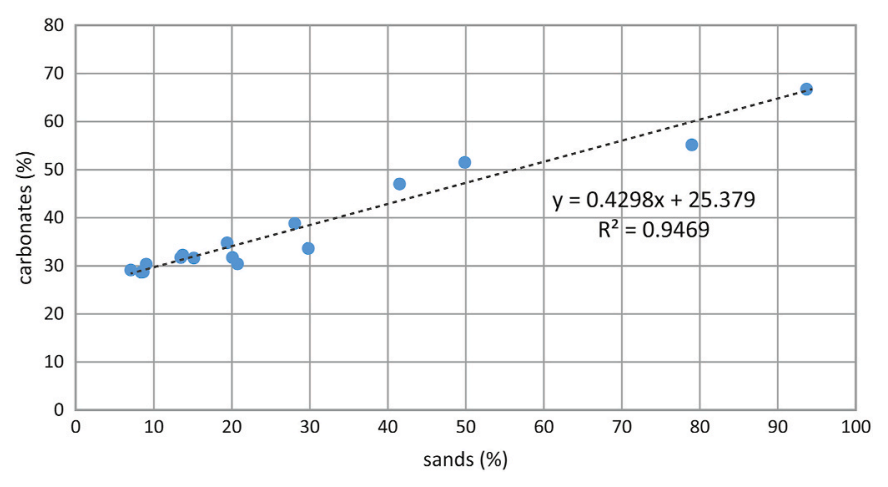

Fig. 7. Correlation between carbonates and sands in $\mathrm{T} 1$ deposits. Example of Tang-e Bolaghi section (PAS17G-TB01).

north-east of the modern village of Pasargadae, including the archaeological site (Fig. 3). The sector of Dehno was thus the object of a geoarchaeological study to detect in the sections of the alluvial layers indications for the presence of the departure points of earliest canals and perhaps the persistence of the strategy of irrigation over the long term in this part of the plain.

The sequence studied corresponds to a section in an alluvial terrace of about $6 \mathrm{~m}$ high, located in the topographic continuation of the plain. The section shows, from base to top, above $1 \mathrm{~m}$ of non-visible deposit, three different units (Fig. 8): a coarse level with sandy lenses, of about $2 \mathrm{~m}$; a silty to silty-sandy strata, even sandy-silty, of about $2 \mathrm{~m}$; a carbonated level with concretions, of variable thickness, up to about $0.5 \mathrm{~m}$, containing a large percentage of centimetric rhizoliths and shells (molluscs). The top of the section (about $1-2 \mathrm{~m}$ ) is not visible.

Samples for sedimentary analysis were taken in the fine levels above the coarse units at the base of the section. Grain size analysis shows that these levels consist of two parts, a coarser basal unit that is sandy-silty, with a substantial proportion of sands: from 42 to $46 \%$ (49-54\% of silts); a finer upper unit, silty-sandy, with a high proportion of silts: $67-70 \%$ (26-29\% of sands). Measurement of carbonate content indicates a very high proportion of fine sediments, from 40 to $60 \%$ for the samples originating from the unit with carbonated concretions. Finally, the quantity of organic material is very low in all strata: between 1 and $1.4 \%$ (Table 5 for detailed results).

Radiocarbon and post-IR IRSL dating were carried out for the fine levels of the upper half of the section. The dates for charcoal correspond to the post-IR IRSL dates (Table 2 and Table 1). The stratum at the base of the fine levels yielded a date of $1325 \pm 35 \mathrm{BP}$ for the charcoal and 1.6 \pm 0.1 ka for the post-IR IRSL; the carbonated unit situated above was dated by radiocarbon to $1195 \pm 30 \mathrm{BP}$, and to $1 \pm 0.1 \mathrm{ka}$ by post-IR IRSL.

4.2.2.2. The stratigraphic sections in the valley of the Sarpaniran. A main tributary of the Pulvar river flows into the Sarpaniran valley, at the south-east end of the Pasargadae plain (Fig. 1). The side of the valley consists of alluvial/colluvial Pleistocene deposits, nowadays observable as eroded pediments. The late deposition of material on the valley bottom forms a terrace $1-3 \mathrm{~m}$ high. In the thickest section, it presents the following profile (Fig. 9A): a coarse first level with heterometric blocks (30-40 cm in length) at $2 \mathrm{~m}$; an upper level, at $1 \mathrm{~m}$, of fine sediments sometimes with a few scattered stones. The sedimentary analysis of the upper level indicates that it is a silty unit, highly carbonated by precipitation (Fig. 9B).

This alternation, although weak, is similar to the succession observed on terrace $\mathrm{T} 2$ in the plain. The dates obtained through radiocarbon in the upper level range from $850 \pm 30 \mathrm{BP}(1206 \pm 54 \mathrm{cal}$. CE) at a depth of $90 \mathrm{~cm}$, to $330 \pm 30 \mathrm{BP}(1560 \pm 83 \mathrm{cal}$. CE at $30 \mathrm{~cm}$ from the top (Table 1). The first date is not far from that obtained from terrace $\mathrm{T} 2$ in the upper part of the fine levels at Dehno $(1 \pm 0.1 \mathrm{ka}$ and $1195 \pm 30 \mathrm{BP})$ (Table 2). One can presume that the two deposits belong to the same phase. This date thus provides a point of reference for the end of the phase of sedimentation of the Medieval period. As for the second date, it is much later and closer to that of $140 \pm 30 \mathrm{BP}$ (Table 1) obtained for terrace T3 (Rigot, 2010).

\section{Discussion}

\subsection{Holocene fluvial dynamics in the catchment area of the plain of} Pasargadae

Following the deposit of the coarse alluvial layer of the Last Glacial

Table 4

Results of grain size, carbonates and organic content analysis (\%). T1 terrace, Tang-e Bolaghi sections (PAS17-GTB-01/02).

\begin{tabular}{|c|c|c|c|c|c|c|c|c|c|}
\hline Sample code & $0-2 \mu \mathrm{m}$ & $2-20 \mu \mathrm{m}$ & $20-50 \mu \mathrm{m}$ & $50-200 \mu \mathrm{m}$ & $200-500 \mu \mathrm{m}$ & $500-2000 \mu \mathrm{m}$ & carbonates & Organic matter & Altitude (m) \\
\hline PAS 17 GTB 02_14 & 4.13 & 31.99 & 35.03 & 28.66 & 0.2 & 0 & 35.0 & 3.7 & 1824 \\
\hline PAS 17 GTB 02_13 & 3.74 & 36.41 & 47.09 & 12.77 & 0 & 0 & 33.0 & 2.0 & 1823.7 \\
\hline PAS 17 GTB 02_11 & 6.5 & 38.26 & 28.96 & 26.07 & 0.21 & 0 & 31.6 & 2.2 & 1823.2 \\
\hline PAS 17 GTB 02_10 & 3.67 & 25.1 & 31.25 & 38.78 & 1.19 & 0 & 40.7 & 2.1 & 1822.7 \\
\hline PAS 17 GTB 02_08 & 7.89 & 52.1 & 27.06 & 12.59 & 0.37 & 0 & 31.0 & 1.5 & 1822.2 \\
\hline PAS 17 GTB 02_07 & 6.84 & 53.37 & 28.26 & 10.85 & 0.68 & 0 & 29.4 & 3.1 & 1821.8 \\
\hline PAS 17 GTB 02_06 & 5.54 & 35.84 & 26.74 & 29.23 & 2.65 & 0 & 28.4 & 4.5 & 1821.3 \\
\hline PAS 17 GTB 02_04 & 3.5 & 19.45 & 19.25 & 50.24 & 7.56 & 0 & 43.8 & 2.7 & 1821 \\
\hline PAS 17 GTB 02_03 & 5.85 & 37.09 & 35.61 & 21.28 & 0.16 & 0 & 32.5 & 5.8 & 1820.8 \\
\hline PAS 17 GTB 02_01 & 0.62 & 4.04 & 0.16 & 1.16 & 28.86 & 65.15 & 73.1 & 1.2 & 1820.3 \\
\hline PAS 17 GTB 01_23 & 6.11 & 44.29 & 34.47 & 14.89 & 0.24 & 0 & 31.7 & 4.2 & 1819.8 \\
\hline PAS 17 GTB 01_22 & 6.88 & 51.27 & 28.38 & 12.79 & 0.68 & 0 & 31.8 & 3.9 & 1819.1 \\
\hline PAS 17 GTB 01_20 & 4.45 & 26.36 & 19.33 & 31.46 & 17.26 & 1.14 & 51.5 & 3.0 & 1818.6 \\
\hline PAS 17 GTB 01_19 & 7.48 & 44.31 & 20.13 & 19.35 & 8.69 & 0.03 & 38.8 & 3.5 & 1818.2 \\
\hline PAS 17 GTB 01_17 & 6.57 & 37.06 & 14.87 & 13.71 & 23.94 & 3.85 & 47.0 & 2.4 & 1817.7 \\
\hline PAS 17 GTB 01_16 & 7.32 & 44.32 & 28.98 & 16.75 & 2.6 & 0.03 & 34.8 & 2.5 & 1817.4 \\
\hline PAS 17 GTB $01 \_14$ & 0.55 & 4.72 & 1.04 & 3.06 & 34.72 & 55.88 & 66.8 & 0.7 & 1816.9 \\
\hline PAS 17 GTB 01_13 & 3.19 & 31.66 & 44.44 & 20.71 & 0.001 & 0 & 30.4 & 1.2 & 1816.3 \\
\hline PAS 17 GTB $01 \_11$ & 4.86 & 34.57 & 40.5 & 20.07 & 0 & 0 & 31.8 & 2.0 & 1815.8 \\
\hline PAS 17 GTB 01_10 & 5.27 & 56.09 & 31.61 & 6.8 & 0.23 & 0 & 29.2 & 2.0 & 1815.3 \\
\hline PAS 17 GTB 01_09 & 5.89 & 56.4 & 29.32 & 8.39 & 0 & 0 & 28.7 & 3.0 & 1814.8 \\
\hline PAS 17 GTB $01 \_07$ & 6.55 & 48.16 & 36.63 & 8.66 & 0 & 0 & 28.8 & 1.9 & 1814.5 \\
\hline PAS 17 GTB 01_05 & 7.38 & 45.94 & 32.99 & 13.11 & 0.58 & 0 & 32.3 & 1.7 & 1814 \\
\hline PAS 17 GTB 01_04 & 5.02 & 45.56 & 40.39 & 9.03 & 0 & 0 & 30.4 & 2.2 & 1813.3 \\
\hline PAS 17 GTB 01_02 & 2.74 & 10.89 & 7.4 & 52.58 & 26.38 & 0.0006 & 55.2 & 1.0 & 1812.8 \\
\hline PAS 17 GTB 01_01 & 4.34 & 27.48 & 38.38 & 29.76 & 0.04 & 0 & 33.6 & 1.7 & 1812.4 \\
\hline
\end{tabular}



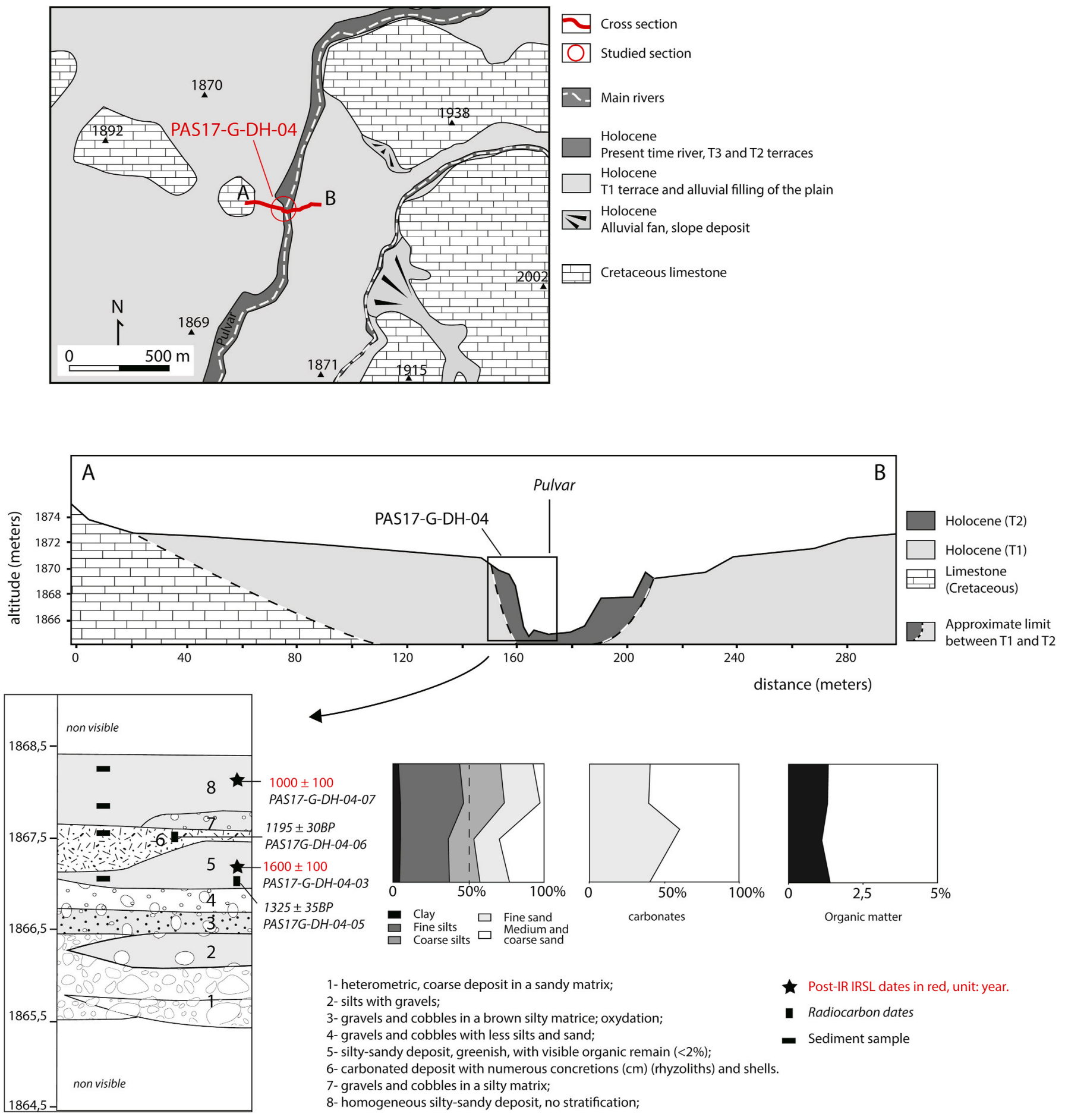

Fig. 8. Dehno site, Pasargadae plain, centre of the Pulvar Watershed: Pulvar valley profile, geomorphological units, study of the section (T2).

Table 5

Results of grain size, carbonates and organic content analysis (\%). T2 terrace, Dehno section (PAS17-GDH-04).

\begin{tabular}{llllllllll}
\hline Sample code & $0-2 \mu \mathrm{m}$ & $2-20 \mu \mathrm{m}$ & $20-50 \mu \mathrm{m}$ & $50-200 \mu \mathrm{m}$ & $200-500 \mu \mathrm{m}$ & $500-2000 \mu \mathrm{m}$ & carbonates & Organic matter & Altitude (m) \\
\hline PAS 17 GDH 04_08 & 3.73 & 40.1 & 27.34 & 21.63 & 7.18 & 0.01 & 40.2 & 1.3 & 1867.9 \\
PAS 17 GDH 04_04 & 5.02 & 42.08 & 27.09 & 23.26 & 2.56 & 0 & 39.2 & 1.3 \\
PAS 17 GDH 04_02 & 4.53 & 31.8 & 17.16 & 16.93 & 16.66 & 12.91 & 59.9 & 1.1 & 1867.4 \\
PAS 17 GDH 04_01 & 3.91 & 33.53 & 20.52 & 19.07 & 19.42 & 3.55 & 39.8 & 1.4 & 1867.1 \\
\hline
\end{tabular}




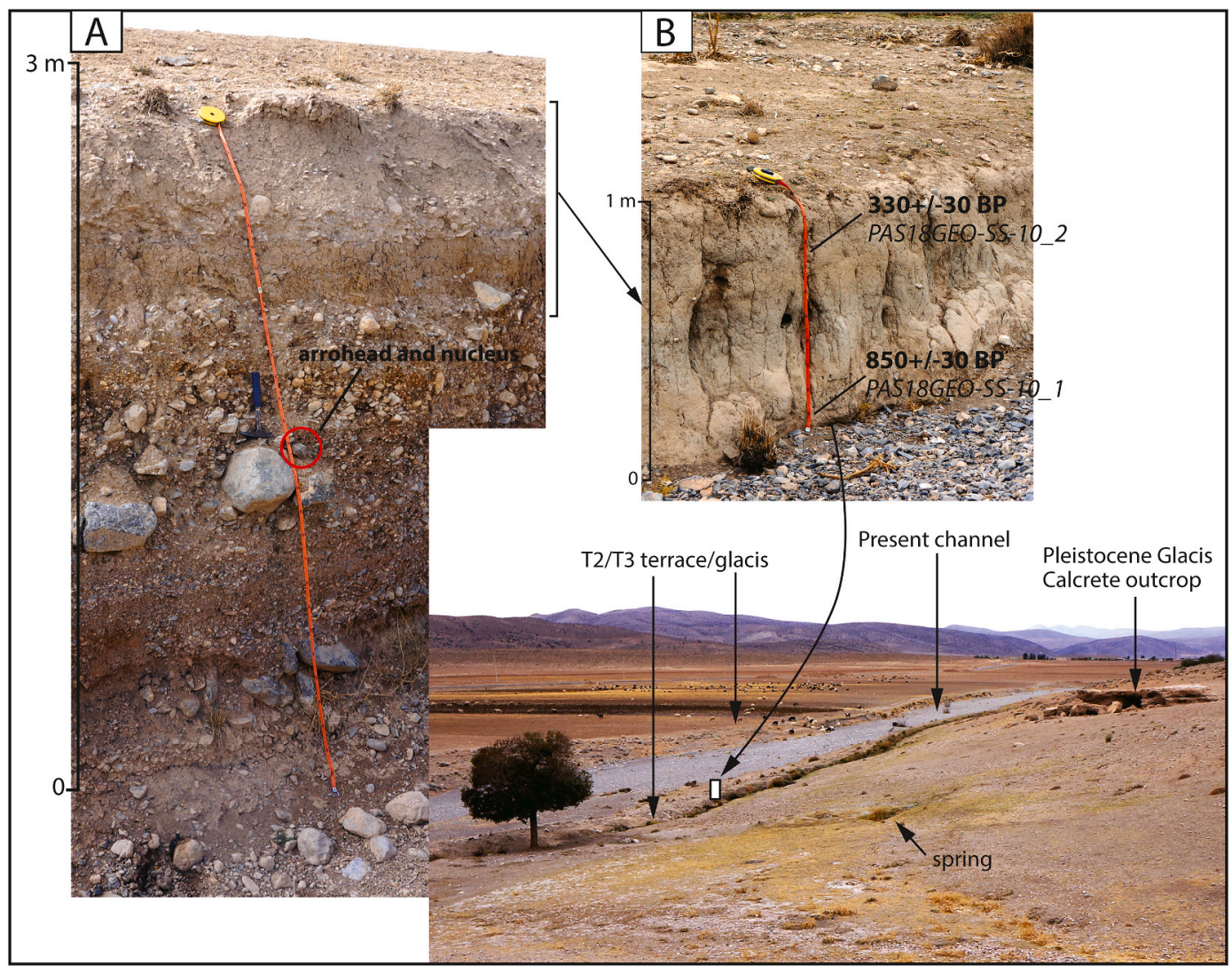

Fig. 9. Sarpaniran valley, south-east of the Pasargadae plain: geomorphological units and sections (T2-T3).

Maximum (LGM), the three terraces present today in the valley of the Pulvar correspond to three major phases of sedimentation, followed by episodes of incision (Fig. 2; Fig. 10). This preserved evidence of morphogenetic processes illustrates the floodplain aggradation dynamics during the Holocene.

The $\mathrm{T} 1$ alluvial unit reflects a major phase of sedimentary accretion

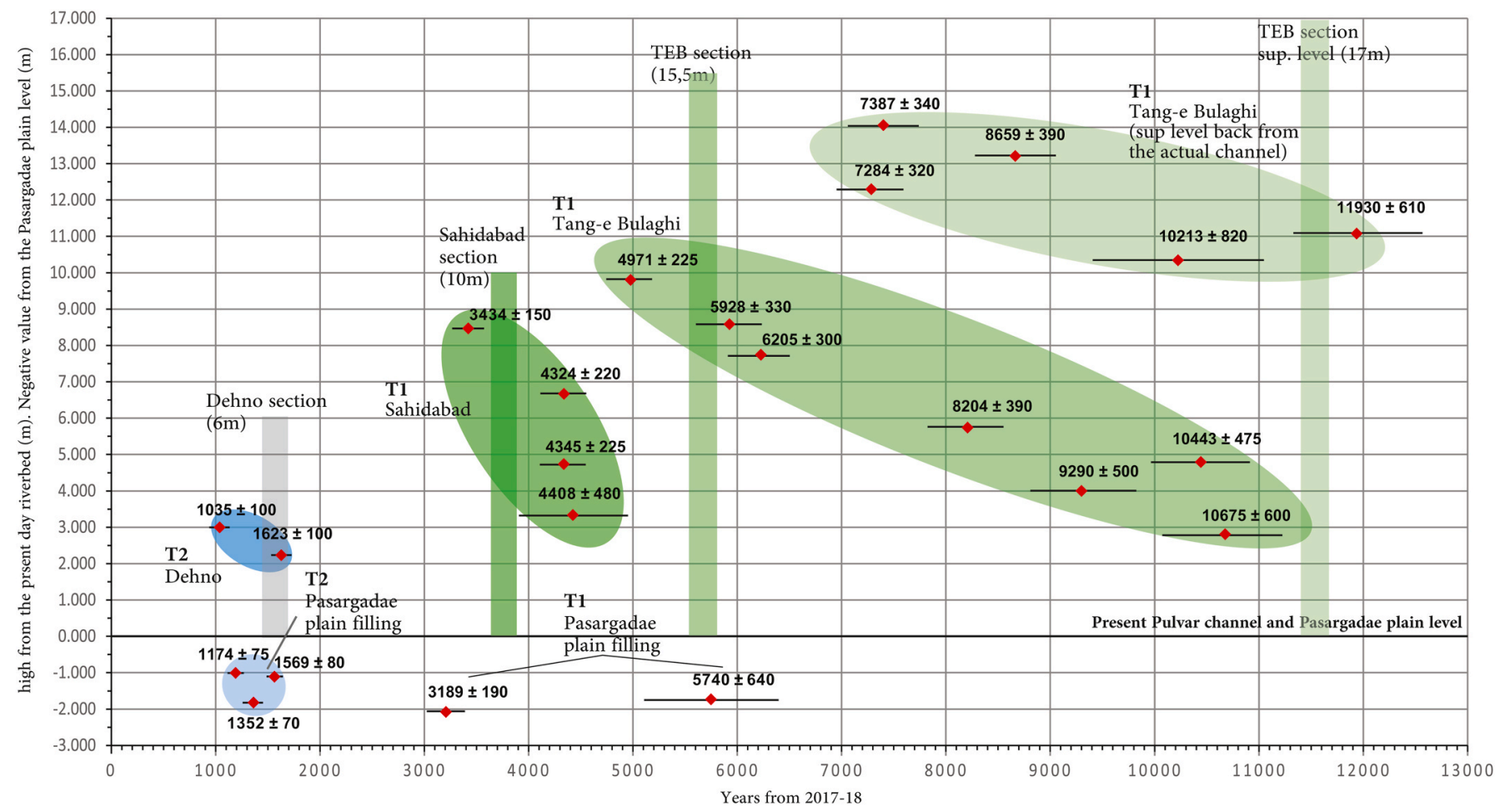

Fig. 10. Post-IR IRSL dates of the alluvial deposits and their topographic position. 
over a long period. According to our observations and dating in the Tang-e Bulaghi area, this sedimentation would have begun at least at the beginning of the Holocene, and ended in the early 1st millennium BCE. In Shahidabad, the deposit belong to the same phase but the chronology is less clear due to dating inaccuracies.

Concerning the Tang-e Bolaghi, the thickness of the layer reaches $16-17 \mathrm{~m}$. The post-IR IRSL dates obtained range from about $10 \mathrm{ka}$ at a depth of $13 \mathrm{~m}$ (alluvial floor of T1) to $5 \mathrm{ka}$ at a depth of $6 \mathrm{~m}$ It can be stated that the first $11 \mathrm{~m}$ were deposited at the end of the 4th millennium BCE (Fig. 10). This chronology is confirmed by the work carried out on the plain of Tang-e Bolaghi, a few kilometres downstream, where a Chalcolithic site (Bakun culture, 4800-4100 BCE) was found at a depth of $3 \mathrm{~m}$ (Helwing et al., 2010). A few age reversals can be noted in the Tang-e Bulaghi sections (PAS17-GTB-01 and 02) (Fig. 10). They might have been caused by insufficient bleaching. Indeed, the samples come from sandy levels, having probably gone through a high rate of sedimentation. As regards the dates of the second T1 section in Tang-e Bulaghi (PAS-GTB-02, Fig. 6), the reversal age could be partly explained by bleaching problems and partly by geomorphic phenomenon. Thus, regarding the deposition dynamics, we can presume a lateral and vertical accretion along concave banks. However, we don't have enough scientific elements to argue this hypothesis, which is not fully satisfactory. So this result will not be used in our chronology model.

Concerning the terrace of Shahidabad, whose thickness reaches $10 \mathrm{~m}$, the first $6 \mathrm{~m}$ were deposited before the first half of the 3rd millennium BCE. Above the latter, a sedimentary change occurred, the facies of the layer becoming very coarse, similar to that of a channel, while in the Tang-e Bolaghi the deposits remained rather homogenous, with, however, the presence of some sandy channels. According to our dating, the rate of sedimentation grew significantly in the central part of this coarse layer, during the second half of the 3rd millennium BCE. This could partially explain the proximity between the dates. A bleaching problem could also explain the similarity of the IRSL dates. Finally, the top part of the layer would have begun its deposition in the second half of the $2{ }^{\text {nd }}$ millennium BCE. The non-dated last $1.5 \mathrm{~m}$ was probably deposited quite rapidly because they were in place before the arrival of the Achaemenids, who created the levee on it during the second half of the 6th century BCE (Fig. 10).

Other dates obtained in trenches opened at the site of Pasargadae permitted clarifying the infilling of the plain, in relation to T1. A post-IR IRSL date at $3.2 \mathrm{ka}$ was obtained at a depth of 2m (PAS17-PAL-06-01) (Tab 2, Fig. 10) and a radiocarbon date of between 750 and 400 cal. BCE at a depth of 1.3m (PAS18G-PP3-1-3, Table 1).

The following geomorphic phase is characterised by a very large incision (14-16m in the gorges of the Tang-e Bolaghi) in the $\mathrm{T} 1$ alluvial layer. It can be placed between the end of the 1st millennium BCE and the first half of the 1st CE, since the upper half of terrace T2 was created during that period (perhaps somewhat earlier). We thus consider sedimentation of terrace T1 to have ended around 500 BCE and been followed by a hypothetic short phase of geomorphic stability.

A new major sedimentation phase followed, as seen in the presentday remains of terrace T2. The dates obtained confirm a formation of layer T2 in the plain during the Medieval period (Rigot, 2010) (Fig. 10). The two very distinct phases that characterize alluvial layer T2, illustrated by a coarse unit followed by several units of fine sediments, can be observed elsewhere apart from the Pulvar. They appear to be an indication of a regional morphogenetic variation. First, these deposits reflect a dynamics of torrential flow during the first half of the 1st millennium $\mathrm{CE}$ (one cannot be more precise because of the lack of dates from this level), which led to the accumulation of a coarse sequence. As may be noted at Dehno, there was a change in dynamics from the 5th-6th c. CE to the 11 th or even the 13 th $\mathrm{c}$. CE, leading to a more regular flow marked by very frequent high-water episodes and the deposition of fine particles. The presence of levels of rhizoliths in the Dehno terrace suggests the permanence of a superficial water level and the establishment of marshy areas in the alluvial plain. Indeed, the very good state of preservation of rhizoliths and shells suggests that they began to fossilise in situ, because they were deposited in the same positions once the organism had died (Brazier, 2018). During this period, the watercourse of the Pulvar was probably in braids and/or anastomoses, which would explain the large aggradation at the bottom of the valley.

In the Sarpaniran valley, the same tendency can be observed, but to a much lesser degree. The intermittent tributaries were first of all transit zones for material that later accumulated on the plain. A small part accumulated in the channels before being partially removed by erosion. Our observations thus revealed a pattern of behaviour, which, during the major part of the Holocene and all of the period of the formation of $\mathrm{T} 1$, was completely different in the case of this drainage channel, when compared to that of the Pulvar. The way this tributary operated is thus typical of a dryland river (Graf, 1988; Powell et al., 2007). However, during the Medieval period, the morphogenesis was similar to that observed on the plain, in terrace T2.

The phase that followed consisted of an intense and relatively brief incision of the whole of the Medieval alluvial layer (right up to $10 \mathrm{~m}$ thick in the Pulvar's bed), which formed terrace T2. This episode occurred in the 2nd millennium CE, probably between 1100 and 1200 $\mathrm{CE}$, if one accepts the date obtained in the terrace of the Sarpaniran. The incision continued at least until 1500-1600 cal. CE, the date for the upper level of the Sarpaniran's terrace, or maybe earlier if one accepts the date of the very low terrace observed in the Pulvar (T3) (Post-1650 cal. CE, Tab 1). Anyway, this slight difference in chronology indicate that the phenomenom of incision of T2 and deposition of T3 has been complex and probably not contemporaneous between the tributaries and the Pasargadae plain. Finally, the last noticeable morphological process is a phenomenon of incision that exposed T3 recently. The present-day dynamics are weak, and appear as sporadic phenomena of intense high-water, which have led to the occasional remobilization of the bedload.

\subsection{Comparisons of geomorphological data on a regional scale}

Our work permitted clarifying the chronology of landscape formation during the Holocene, as well as suggesting new hypotheses concerning geomorphological dynamics. The three terraces present today in the Pulvar valley can also be seen in the plain of Persepolis (Rigot, 2010; Kehl et al., 2005, 2009) and thus characterize the whole of the catchment area of the Kur/Pulvar system. The formation of T1 and then its incision constitute the major geomorphological events of the Holocene in the region. A comparison with data on a macro-regional scale clarifies this pattern of interpretation.

In the plain of Persepolis, Kehl et al. (ibid.) obtained much older OSL and C-14 dates from the palaeo-soils buried in the upper terrace of the Kur river. They all come from the lower half of the stratigraphic section. Based on these results, they estimate that the formation of the soil dated to $27-22$ ka required a long phase of morphological stability. They thus date the beginning of the final deposit of the alluvial cover to $21 \mathrm{ka}$, with continuation up to $7 \mathrm{ka}$ that includes interruptions during which pedogenesis developed. This layer would have been deposited under dryer and cooler conditions. In parallel, the river would have begun its incision $10 \mathrm{ka}$ ago, and sedimentation by overflow in low-lying sectors would have resumed. The major difference in chronology with the study by Kehl et al. (2009) relates to the beginning of the deposit of layer T1, which for these scholars appears to be the earliest. It is certain that in the sectors studied along the Pulvar, layer T1 began its deposition earlier than the oldest dates that we have obtained. In the Tang-e Bolaghi, beneath the dated level at a depth of $13.1 \mathrm{~m}$, there are, for example, approximately $4-5 \mathrm{~m}$ that have not been dated. We must therefore push back the beginning of sedimentation for $\mathrm{T} 1$ by a few thousand years to probably the end of the LGM, around 13 to $14 \mathrm{ka} \mathrm{BP}$. The period would have been marked by more favourable conditions for these dynamics, as demonstrated by several palaeo-ecological studies from north-western Iran (Bottema, 1986; Wasylikowa et al., 2008; Aubert et al., 2017). 
However, even when taking this estimation into account, we are still far from the chronology proposed by Kehl et al. (2009).

As regards the C-14 dates of Kehl, we have regularly encountered substantial age inversions during palaeo-environmental investigations of several lakes and wetland complexes in the Persepolis and neighbouring plains (Djamali et al., 2018). The C-14 ages are too old, due to contamination by young carbon (root systems) and old carbon (reservoir and hard-water effects). For example, at Lakes Maharlou (Brisset et al., 2019) and Urmia in NW Iran (Sharifi et al., 2019), the dated fossils, which can partly absorb dissolved old organic carbon, have yielded dates several centuries older and younger than contemporaneous sediments. The humic acids dated by the radiocarbon technique as mentioned by Kehl et al. (2009) may also have been contaminated by old organic carbon.

This difference in dates obtained on the plains of Pasargadae and Persepolis could also be related to neo-tectonic phenomena. The coarse LGM layer is absent in the stratigraphic sections studied by Kehl et al. (ibid.). A recurrent phenomenon of subsidence in the Pleistocene and the Holocene may have occurred in the Marvdasht plain, which would have constrained the deposition of material in suspension, whereas the bedload may have been deposited farther upstream (Bravard and Petit, 1997). The beginning of the incision of T1 also appears to have been earlier in the Kur valley and is estimated to be $10 \mathrm{ka}$ by Kehl et al. (2009). In the Pulvar valley, however, 10 ka corresponds almost to the beginning of the phase of sedimentary accretion. Had this change had a climatic origin, it would have certainly affected the whole of the Kur/Pulvar catchment area.

These neo-tectonic phenomena could also explain the nature of sedimentation in this mountainous region. It is above all the folds of the Zagros plateau that explain the strong accumulations of fine particles on the plains (Ramsey et al., 2008). They developed in the synclines that followed each other, separated by an anticline incised by the rivers in the shape of north-south gorges. On the one hand, plugging phenomena may have occurred at the entrance of these gorges, causing the slowdown of water flows and the deposit of fine particles in the plains. The very high rate of sedimentation in the Sahidabad section can be explained by this phenomenon. On the other hand, variations in the base level, because of the shortening of the Zagros plateau in progress (Fontugne et al., 1997; Uchupi et al., 1999; Tatar et al., 2002; Blanc et al., 2003; Vernant et al., 2004), could have contributed to slow down and disorganize the watercourses and cause the deposition of fine sediment particles, resulting in considerable thickness of deposit. This process is quite frequent in intermontane basins; they can become endorheic when the secondary mountain ranges located downstream from the catchment areas rise more rapidly than the incision of the watercourses (Delcaillau, 2004). The abrupt change in length of the Pulvar's profile, measured in the plain of Pasargadae, is perhaps, therefore, evidence of neo-tectonic activity. The proclivity of the channels to this type of phenomenon has been observed in other regions of the Zagros, with, at times, important variations within the same catchment area (Obaid and Allen, 2019). The regional differences in neo-tectonic dynamics should be more precisely analysed at the scale of the very large catchment area of the Kur/Pulvar.

Finally, these chronological differences could also reflect the different readings and interpretations of the geomorphological dynamics that led to the formation of T1. For Kehl et al. (2009), followed by De Schachtet al. (2012), thesilty sedimentshave an Aeolic origin and belong to the loess or the pseudo-loess reorganised by the watercourses of the region. The early dates obtained in the plain of Persepolis corroborate this scenario quite well. Indeed, our observations along the eroded glacis of the Pulvar valley suggest a much more local origin for these sediments. These forms and formations appear to be inherited from the Plio-Pleistocene deposits and their erosion during the main glacial/interglacial phases of the Pleistocene. The shaping of the most recent glacis (a carbonated detrital cover), whose level corresponds, downstream, to the alluvial floor of the plain of Pasargadae might have resulted in most of the fine carbonated sedimentary material that constitutes the greater part of alluvial terraces. Indeed, our observations show that the sedimentary particles of T1 are mainly made of carbonate silts and sand grains and confirms that the high levels of carbonates do not result from in situ precipitation. In the interpretations proposed by Kehl et al. (2009), the lateral sediment contributions coming from the erosion of slopes and glacis are not considered. Moreover, the presence of channels at different elevations in the thickness of the T1 terrace was not mentioned by Kehl et al. (ibid.). These channels show a river that regularly changed its bed in an alluvial plain that was rising.

\subsection{Cross-analysis with the existing palaeo-environmental data}

From a hydro-morphological viewpoint, the silty deposits, homogenous and relatively well sorted, were deposited by a perennial watercourse (Graf, 1988; Tooth, 2000). This observation was true only for the Pulvar, and not its tributaries, which appear to have been mostly intermittent throughout the Holocene. However, in present climatic conditions associated with increasing human exploitation, the Pulvar is no longer perennial. One can thus presume that at the end of the LGM, right up to the mid-Holocene, more humid conditions would have been enough to maintain a more stable hydrological regime.

Such conditions can be imagined in the case of different climate seasonality. The early to middle Holocene in continental south-west Asia (including the Zagros Mountains) was marked by hydroclimatic and ecological conditions that differed from those of northern temperate latitudes (Wright et al., 2003). While stable isotope records suggest higher lake levels, pollen diagrams reflect the persistence of glacial dry steppes (Roberts, 2002; Stevens et al., 2001, 2006; Wright et al., 2003; Jones and Roberts, 2008; Djamali et al., 2010). Nowadays, a general consensus among palaeo-ecologists and palaeo-climatologists in explaining this paradox is that one of the major intervening factors was seasonality, with precipitations differing in the early Holocene in comparison to the Late Holocene (Jones et al., 2019). It has been suggested that the duration of the dry season was longer during the early Holocene, up to $6.5 \mathrm{ka}$, with most of precipitations falling during the winter months (Stevens et al., 2001, 2006; Djamali et al., 2010). The early Holocene was characterised by lower insolation values during the winter months (Fig. 11). These facts suggest that snowfall and snow accumulation were heavier during the early Holocene, and this increase in snow perennially fed the sources of the Pulvar, located in a high mountain range rising to more than $3850 \mathrm{~m}$. Snow melt during the summer months would have provided a more abundant water supply for the river systems, creating more permanent rivers: this may have been the case of the Pulvar. Finally, the presence of numerous springs north of the plain of Pasargadae (Fig. 1c), would also have contributed to the watercourse's perennial water supply.

In the case of $\mathrm{T} 1$, the transition to late and post-glacial warming conditions would have not led to a reversal of the morphogenesis, and thus to an incision, contrary to what can be observed elsewhere, particularly in temperate environments (Bridgland, 2000). T1 would have been deposited following the coarse Pleistocene layer. The main difference may derive from the origin of the sediments and the particles' grain size. Indeed, as recalled by J. Vandenberghe (1995), local conditions can play a very important role in changes of river activity and the shaping of valleys. With the climatic amelioration, fragmentation of rocks would therefore have decreased upstream from the catchment areas, while erosion would have continued on the denuded slopes and provided the river with particles of much smaller grain size. The progressive snow melt during the long months of spring and summer were sufficient to provide a permanent flow, and enable the transport and sorting of fine sediments throughout the hydrographic network. No changes were noticed in the morphogenesis until the Late Holocene.

The incision phase of $\mathrm{T} 1$ is a break in the dynamics of morphogenesis. Decrease in sedimentary load, which leads to cutting by a river, often has a climatic and/or anthropic origin. It can occur because of a 


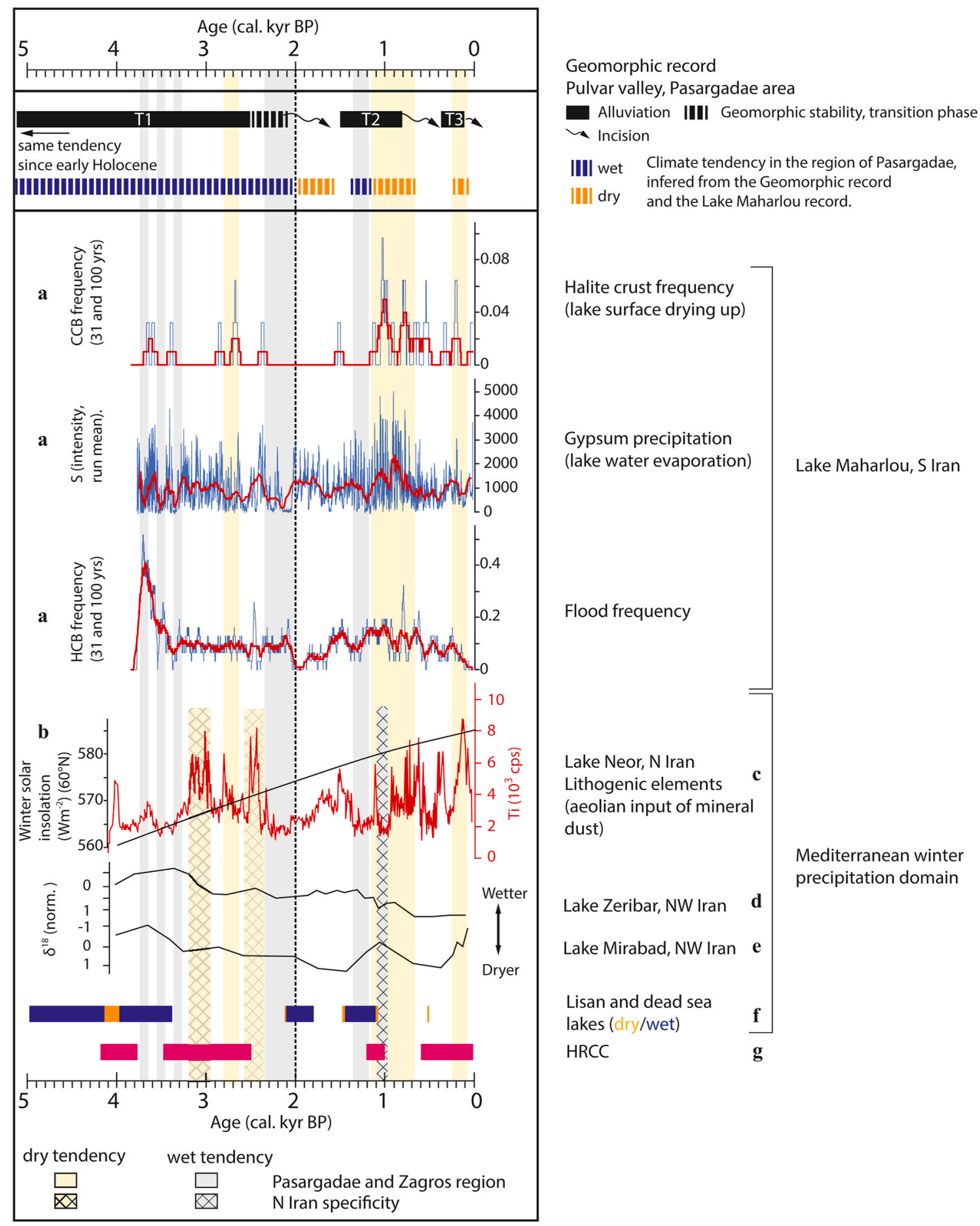

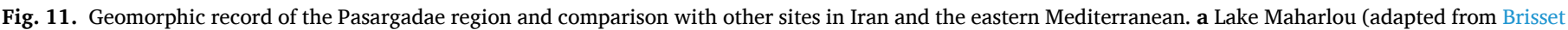

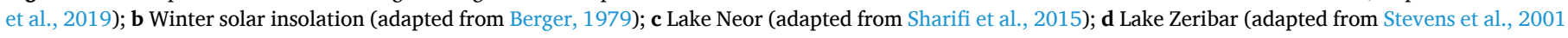

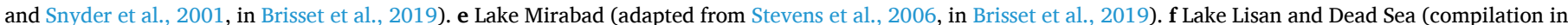
Sharifi et al., 2015); g Holocene rapid climate change events (HRCC) (Mayewski et al., 2004, in Sharifi et al., 2015).

dry spell, but also due to humidification that increases plant density on the slopes. In north-western Iran, a hydroclimatic record at high resolution shows that a change in climate occurred around 2400 cal. BP. This is seen at the end of a dry period and the point of departure of a more humid episode, which lasted until 2000 cal. BP (Sharifi et al., 2015) (Fig. 11). For the Zagros, according to the multi-proxy record of Lake Parishan, a fundamental hydrological change occurred at almost the same time (2400 cal. BP), marked by a rise in lake levels (Jones et al., 2015). The geochemical records for Lake Maharlou, closer to
Pasargadae, suggest a relatively humid phase with abundant fluvial inflow and high lake levels between 3800 and $3300 \mathrm{cal}$. BP. This was followed by a fairly stable hydro-climatic episode up to $2300 \mathrm{cal}$. BP, then by a humid phase of 300 years. Then a drying up of the lake is observed and a decrease in fluvial contribution due to a phase of drought (Brisset et al., 2019). The drying trend around 2000 cal. BP would have led to the phenomenon of incision. Indeed, most of our observations suggest that $\mathrm{T} 1$ ended its formation at the end of the 1st millennium BCE. The Achaemenid levee of Shahidabad confirms this hypothesis, in that it 
was built when the watercourse was very high, overflowing frequently and thus continuing to raise the alluvial floor of the future T1.

The deposit of T2 could have been caused by two phenomena that were probably coupled: a temporary rise in precipitation and intensive cultivation during the Medieval period (Saeidi Ghavi Andam et al., 2020). The climatic modification would have favoured a return of erosion on the slopes and an increase in the Pulvar's sedimentary load (Fig. 11). This phenomenon would have led to the formation of a coarse basal unit. The fine levels above might have been deposited in a slightly dryer climatic context in comparison to the beginning of this sequence, characterised by intense agricultural exploitation, as demonstrated by regional multi-proxy records and the development of Islamic/Medieval settlements in the plain of Pasargadae. Cultivation could have contributed to the increase of soil erosion leading to the sedimentation of thick fine levels in the fluvial channels and lake basins like demonstrated at Maharlou (Djamali et al. 2009; Brisset et al., 2019). It is moreover striking that the fine Medieval level has been observed in the Pulvar in the plain of Pasargadae and in the valley of the Sarpaniran, downstream from extensive cultivable sectors.

The morphological evidence for this later episode of sedimentation is quite rare on the Iranian plateau. The observations and interpretations based on this evidence, not always using the same time scale, are often contradictory. In their assessment of the environment in the Pleistocene and the Holocene in eastern Iran, Walker and Fattahi (2011) thus highlight the absence of evidence for morphological activity in the late Holocene, because of aridification. Conversely, in the lake of Maharlou, Brisset et al. (2019) report a detritic phase dated to 1.3 to $1.1 \mathrm{ka}$ BP, somewhat contemporary with the $\mathrm{T} 2$ sedimentation, that would perhaps reflect a short, more humid episode (Fig. 11). It is above all in the work of Kehl et al. (2005, 2009) that this later morphogenesis is appropriately noticed thanks to at least two dates obtained in the Marvdasht plain.

The latest incision phase, very intense and occurring over a relatively short time, may have been caused by a relative dry climatic spell that brought a decrease in the level of the regional base. It is interesting to note that this phase of incision appears to coincide with a well-defined episode of drought recorded in Lake Maharlu (Brisset et al., 2019). The first very intense phase of drought lasted four centuries (900-1300 $\mathrm{AD}$ ), the lake levels remained quite low afterwards, as did fluvial activity. They have been decreasing until today (Fig. 11).

Finally, the formation of T3 could be related to a climate that remained relatively stable but dry, with an intensification of agro-sylvopastoral activities that caused soil erosion and provided fine sedimentary material. Pollen records from several sites across the Iranian plateau suggest that these activities intensified during the last 5 centuries (Van Zeist and Bottema, 1977; Djamali et al., 2009b; Talebi et al., 2016).

\subsection{Management of water resources during the 1st millennium BCE in the} plain of Pasargadae and adaptation to the palaeo-environmental context

The combination of archaeological data with the results of geomorphological and palaeo-environmental analyses permits a better definition of the strategies of exploitation of water resources during the second half of the 1st millennium BCE, as well providing an explanation for the particular morphology of hydraulic systems during this period.

The canal systems known for this period are all located in the foothills surrounding the plain, at altitudes that are very high in relation to the present base level of the Pulvar and most of its tributaries. Apart from the systems of Abulvardi, they are fed by surface waters drained by the hydrographic network. In the present geomorphological context, with highly incised watercourses, the water supply to these ancient canals would appear to be very unreliable. In the 1960s, the morphology of traditional irrigation systems in a hydrographic context close to that of today was completely different. The canal systems fed by the Pulvar or its tributaries were all located in the alluvial plain, the water being carried by head canals over several kilometres from intake points in the river bed. Only the canals fed by karstic springs in the northern part of the plain could flow at a higher elevation.

The morphology of the ancient hydraulic systems in the Pasargadae region is perfectly adapted to the hydrographic conditions as reconstructed by geomorphological and palaeo-environmental studies. This study shows how at the beginning of the 1st millennium, terrace T1, which is today the main alluvial infilling of the plain, was already mostly in place and that the river began its phase of incision. The populations of the 1st millennium BCE thus disposed of vast surfaces of arable land. The levels of the riverbeds being much higher, it was possible to build canal systems on the glacis at higher altitudes and develop them over longer distances. As shown for the Ju-i Dokhtar system, these higher levels of flow enabled a management of water resources over the entire catchment area east of the plain of Pasargadae, by balancing water supplies between upstream zones that were better watered than downstream ones.

The environmental analyses also tend to demonstrate that the flows of watercourses were much stronger than those of today, although they remained affected by a strong seasonality. This can partly explain the reason for the construction of several large dams, for example at the outlet of the Ju-i Dokhtar canal. This water storage strategy appears to be specific to periods of Antiquity, as such structures are practically absent in the sub-recent or recent hydraulic landscape. Since the winter and spring flows were much stronger during the 1st millennium, it was possible to create large reservoirs to feed irrigation systems downstream all year long. In addition, the higher position of the active channel must have led to more frequent flooding. From that time on, these reservoirs were also used as retention basins and played a part in flow regulation.

As demonstrated by the morphology of the systems dated to the 1st millennium BCE and pollen analysis (Djamali et al., 2011b), it is certain that the populations developed irrigated farming and favoured the exploitation of fluvial waters. We also note that the abundance of karstic springs in the northern part of the Pasargadae plain and associated wetlands constitute supplementary water resources that could have contributed to the development of large-scale agriculture (for Persepolis see Djamali et al., 2018). Their abundant flow has favoured occupation in this sector since the Chalcolithic, as recorded by our team during archaeological surveys carried out in 2018. However, we have no reliable data concerning use of these springs during the 1st millennium BCE. The underground water resources must have been less attractive or required heavier techniques in order to be exploited. In the region of Fars, we have no data concerning the development of qanat systems during this period. The qanats in the Pasargadae plain are of limited size and were probably created much later, during the late Medieval centuries. The study of ancient hydraulic systems in the Pasargadae region shows that mastery of the qanat technique, sometimes linked to the Achaemenid expansion (English, 1998), was therefore not a prerequisite for the development of agricultural production on the Iranian Plateau, but rather a local technical solution to given hydrological and hydrogeological conditions (Boucharlat, 2017).

Finally, the development of these multiple hydraulic structures indicates a high exploitation of surface flows. This could have had an impact on hydrological dynamics, which so far, we have not been able to define and clarify for the 1st millennium BCE by looking at the sedimentary archives. Nevertheless, one can presume that the dams retained at least a part of the sediments in suspension in the watercourses. Moreover, tapping into the watercourses may have influenced the fluvial dynamics and contributed, for example, to accelerate the strong dynamics of incision of the Pulvar's river bed.

\section{Conclusion}

The present paper focused on the morphogenesis of the Pasargadae region during the Holocene and, in particular, during the Achemenid period (6th-4th century BCE), emphasizing its links with human occupation. A first major aggradation phase occurred during from the early to the mid-Holocene (10-11 ka to $3.5-2.5 \mathrm{ka} \mathrm{BP})$. It can be seen nowadays 
as a huge alluvial terrace called T1, which filled the Pulvar river valley and the Pasargadae plain. Two other major phases of aggradation were identified and studied: a Medieval alluvial deposit (T2, 1500-800 BP), contemporaneous with the Islamic period, and a modern alluvial one restricted in surface (T3, post $300 \mathrm{BP}$ ). This Holocene aggradation trend was interrupted by two major episodes of incision, the first approximatively dated to the beginning of the first millennium BCE (end of T1 aggradation), and the second to the first half of the second millennium CE (end of T2 aggradation).

As opposed to what occurs in temperate regions, aggradation phases seem to be related to more "humid" episodes that accelerate erosion on the slopes. Incision phases may bear a relation to dry episodes, which contributed to lower the regional base level, and/or to neo-tectonics, which could significantly and quickly change the profile of watercourses. At the scale of the Pasargadae region, our team was successful in demonstrating that local conditions also play a crucial role, particularly human activity, topography and lithology.

During the second half of the 1st millennium BCE, the region's watercourses began a phase of rapid incision, which then made access to surface water more difficult. This fluvial regime is confirmed by recent palaeo-environmental data showing that the hydrographic networks of the region most certainly drained larger volumes of water than today.

The morphology of the hydraulic systems dating to this period was adapted to these geomorphological conditions. They were favourable to a strong development of irrigated agriculture, also demonstrated by the results obtained from the palynological study of the lacustrine archives on a macro-regional scale. The topographic position of large dams as well as long systems of canals built during this period reflects, moreover, the highest level of flow in the rivers. Compared to sub-present canals, they were constructed higher up on the slopes. As regards their position, they could have irrigated vast agricultural surfaces, and enabled connections between the catchment areas of several tributaries of the Pulvar. The geomorphological and palaeo-environmental conditions in the 1 st millennium thus allowed the building of interconnected structures to manage water resources on the scale of the Pulvar's catchment area.

Our study also opens several perspectives for research. Concerning archaeology, systematic surveys of the two water systems of the Tang-e Bolaghi were carried out in 2018 and results are being analysed. It would then be necessary to concentrate on the other hydraulic structures. The networks of qanats remain very poorly dated, although they are probably Islamic. They appear to have accompanied a later Islamic/ Medieval phase of development, during which surface water was less accessible and hydrogeological resources began to be exploited. Further work on the still understudied settlement pattern and hydraulic system of these later periods is necessary, since the geomorphological analysis suggests contemporary deep changes in the river regime probably impacted by farming activities. Concerning the geomorphological approach, the speeds of accretion of the different Holocene alluvial layers still need to be clarified by proceeding with a new series for dating the sediments of the plain. This study must be combined with a better characterisation of the processes of pedogenesis related to the different phases of agricultural development. For the Pleistocene, a more refined analysis of the formation of generations of glacis should provide important data on the hydrological and environmental dynamics of the Quaternary's beginnings. These studies should be combined with neotectonic analyses on the scale of the catchment area of the Pulvar/Kur and the impact on fluvial dynamics. Finally, palaeo-botanical studies are in progress to better define the palaeoclimatic and palaeoenvironmental context on a local and regional scale. Analyses have been carried out on sediments sampled at the site of Pasargadae, as well as in several nearby humid zones. We hope also to detect signs of anthropic activity, as the impact of humans on their environment remains one of the great questions requiring answers.

\section{Author contributions}

J.-B. Rigot, S. Gondet, M.-L. Chambrade, M. Djamali, E. ThamóBozsó, K. Mohammadkhani: Conceptualization, Methodology, Writing Original Draft, Writing - Review \& Editing. S. Gondet, K. Mohammadkhani: Project administration, Funding acquisition. J.-B. Rigot: Supervision.

\section{Data availability}

Geoarchaeology, OSL, remote sensing: available. Archaeology: under the national law of the Islamic Republic of Iran on the archaeological heritage and the agreement of the agencies and partners in charge.

\section{Funding}

Since 2015, the archaeological mission at Pasargadae and its surrounding territory has been funded by the French Foreign Ministry and supported by the Iranian Cultural Heritage, Handicrafts \& Tourism Organization. The work detailed in the present article was also supported from 2017 to 2019 by the French National Research Agency (ANR); funding was obtained in the framework of the FRAL-SHS 2016 GermanFrench call (grant number: ANR-16-FRAL-0011-01). Acquisition of satellite imagery was backed by GEOSUD, a project (ANR-10-EQPX-20) of the program "Investissements d'Avenir" administered by the French National Research Agency and by the program "Initiative for Space Innovative Standards" (ISIS) of the French Centre National d'Études Spatiales (CNES).

\section{Declaration of competing interest}

The authors declare that they have no known competing financial interests or personal relationships that could have appeared to influence the work reported in this paper.

\section{Acknowledgements}

The current "Shiraz" field project is managed jointly by K. Mohammadkhani (University Shahid Beheshti) and S. Gondet (Archéorient UMR 5133 CNRS). It is being implemented following an agreement with the Iranian Cultural Heritage, Handicrafts \& Tourism Organization (ICHTO) and its Research Institute for Cultural Heritage and Tourism (RICHT) headed by Dr. Behrooz Omrani. The project benefits from the help and support of the RICHT International and Legal Affairs Office headed by Dr. Monir Kholghi. The scientific program was developed under the supervision and with the scientific agreement of the Iranian Centre for Archaeological Research (ICAR), the archaeology department of the RICHT, directed by Dr. Rouhollah Shirazi. The fieldwork is supported by the entire team of the Pasargadae World Heritage Centre (PWHC), which also provided us with various facilities. The project took place within the framework of a Memorandum of Understanding for Academic and Research Collaborations signed in 2015 by the RICHT and the University of Lyon 2. On the French side, the fieldwork is backed by the French Foreign Ministry Committee for International Archaeological Research, by the French Research Institute in Iran (IFRI) and by the University of Lyon 2/National Centre for Scientific Research (CNRS) via the support of the UMR 5133 Archéorient and of the FR 3747 Jean Pouilloux Maison de l'Orient et de la Méditerranée. The present article was translated from French to English by Elizabeth Willcox (Archéotraduction). The final editing and proof-reading of this paper's English version was done by Martin Makinson (Plygloses traduction).

\section{References}

Adachi, T., 2008. Achaemenid and Post-Achaemenid objects from TB75, TB130 and the general survey. In: Tsuneki, A., Zeidi, M. (Eds.), Tang-e Bolaghi - the Iran-Japan 
Archaeological Project for the Sivand Dam Salvage Area. Iranian Center for Archaeological Research - University of Tsukuba, Tehran-Tsukuba, pp. 121-132.

Aiuvalasit, M.J., Neely, J.A., Bateman, M.D., 2010. New radiometric dating of water management features at the prehistoric purrón dam complex, tehuacán valley, puebla, méxico. J. Archaeol. Sci. 37, 1207-1213. https://doi.org/10.1016/j. jas.2009.12.019.

Asadi, A., Kaim, B., 2009. The Achaemenid building at site 64 in tang-e Bulaghi. ARTA 2009.003. http://www.achemenet.com/pdf/arta/2009.003-Asadi-Kaim.pdf.

Askari Chaverdi, A., 2018. Tang-e Bolaghi: a rural and industrial area of the parse and Pasargadae territories during the Achaemenid period. In: Gondet, S., Haerinck, E. (Eds.), L'Orient est son jardin - Hommage à Rémy Boucharlat. Peeters, Leuven, pp. 1-9.

Askari Chaverdi, A., Callieri, P., 2016. Tang-e Bolaghi (Fars), Sites TB76 and TB77: Rura Settlements of the Achaemenid and Post-Achaemenid Periods. Archaeopress, Oxford.

Atai, M.T., Boucharlat, R., 2009. An Achaemenid pavilion and other remains in Tang-i Bulaghi. ARTA 2009.005. http://www.achemenet.com/document/2009.005-Atai \&Boucharlat.pdf.

Aubert, C., Brisset, E., Djamali, M., Sharifi, A., Ponel, P., Gambin, B., Akbari Azirani, T. Guibal, F., Lahijani, H., Naderi Beni, A., de Beaulieu, J.-L., Pourmand, A., AndrieuPonel, V., Thiéry, A., Gandouin, E., 2017. Late glacial and early Holocene hydroclimatic variability in northwest Iran (Talesh Mountains) inferred from chironomid and pollen analysis. J. Paleolimnol. 58, 151-167. https://doi.org/ 10.1007/s10933-017-9969-8.

Auclair, M., Lamothe, M., Huot, S., 2003. Measurement of anomalous fading for feldspa IRSL using SAR. Radiat. Meas. 37 (4-5), 487-492. https://doi.org/10.1016/S1350 4487(03)00018-0.

Azizi Kharanaghi, H., Fazeli Nashli, H., Nishiaki, Y., 2014. The second season of excavations at tepe rahmat abad, southern Iran. The absolute and relative chronology. Ancient Near E. Stud. 51, 1-32. https://doi.org/10.2143/ ANES. 51.0.3038716.

Bailiff, I.K., Jankowski, N., Snape, L.M., Gerrard, C.M., Gutiérrez, A., Wilkinson, K.N., 2018. Luminescence dating of qanat technology: prospects for further development Wat. Hist. 10 (1), 73-84. https://doi.org/10.1007/s12685-018-0213-x.

Benech, C., Boucharlat, R., Gondet, S., 2012. Organisation et aménagement de l'espace à Pasargades. Reconnaissances archéologiques de surface, 2003-2008. ARTA 2012.003. http://www.achemenet.com/document/2012.003-Benech_Boucharlat Gondet.pdf.

Berger, A.L., 1979. Long-term variations of daily insolation and quaternary climatic changes. J. Atmos. Sci. 35 (12), 2362-2367. https://doi.org/10.1175/1520-0469 (1978) $035<2362:$ LTVODI $>2$.0.CO;2.

Berger, G.W., Post, S., Wenker, C., 2009. Single and multigrain quartz-luminescence dating of irrigation-channel features in Santa Fe, New Mexico. Geoarchaeology 24 (4), 383-401. https://doi.org/10.1002/gea.20271.

Blanc, E.J.-P., Allen, M.B., Inger, S., Hassani, H., 2003. Structural styles in the Zagros simple folded zone, Iran. J. Geol. Soc. London 160 (3), 401-412. https://doi.org/ 10.1144/0016-764902-110.

Bottema, S., 1986. A late Quaternary pollen diagram from Lake Urmia (northwestern Iran). Rev. Palaeobot. Palynol. 47 (3-4), 241-261. https://doi.org/10.1016/0034. 6667(86)90039-4.

Boucharlat, R., 2014. Achaemenid estate(s) near Pasargadae? In: Henkelman, W. Jones, C., Kozuh, M., Woods, C. (Eds.), Extraction and Control: Studies in Honor of Matthew W. Stolper. The Oriental Institute of the University of Chicago, Chicago, pp. 27-35.

Boucharlat, R., 2017. Qanat and falaj: polycentric and multi-Period innovations. Iran and the United Arab Emirates as case studies. In: Angelakis, A.N., Chiotis, E. Eslamian, S., Weingartner, H. (Eds.), Underground Aqueducts Handbook. CRC Press, Boca Raton, pp. 279-301.

Boucharlat, R., De Schacht, T., Gondet, S., 2012. Surface reconnaissance in the Persepolis Plain (2005-2008). New data on the city organisation and landscape management. In: Basello, G.P., Rossi, A. (Eds.), Persepolis and his Settlements. Università di Napoli "L'Orientale", Naples, pp. 123-166.

Bravard, J.-P., Petit, F., 1997. Les Cours D'eau. Armand Colin, Paris.

Brazier, J.-M., 2018. Rôle des phases minérales des sols en tant que réservoirs de nutriments : approche experimentale (abiotique), en milieu naturel et multiisotopique (isotopes stables Ca-Sr). Université de Strasbourg. PhD dissertation.

Bridgland, D.R., 2000. River terrace systems in north-west Europe: an archive of environmental change, uplift and early human occupation. Quat. Sci. Rev. 19 (13) 1293-1303. https://doi.org/10.1016/S0277-3791(99)00095-5.

Brisset, E., Djamali, M., Bard, E., Borschneck, D., Gandouin, E., Garcia, M., Stevens, L., Tachikawa, K., 2019. Late Holocene hydrology of Lake Maharlou, southwest Iran, inferred from high-resolution sedimentological and geochemical analyses. J. Paleolimnol. 61, 111-128. https://doi.org/10.1007/s10933-018-0048-6.

Brown, A.G., 1999. Geomorphological techniques in Mediterranean landscape archaeology. In: Leveau, P., Trément, F., Walsh, K., Barker, G. (Eds.), Environmental Reconstruction in Mediterranean Landscape Archaeology. Oxbow Books, Oxford, pp. 45-54.

Chambrade, M.-L., Gondet, S., Laisney, D., Mehrabani, M., Mohammadkhani, K., ZarehKordshouli, F., 2020. The canal system of Ju-I Dokhtar: new insight into water management in the eastern part of the Pasargadae plain (Fars, Iran). Wat. Hist. 12, 449-476. https://doi.org/10.1007/s12685-020-00271-3.

Chouquer, G., Watteaux, M., 2013. L'archéologie des disciplines géohistoriques. Errance, Paris.

Delcaillau, B., 2004. Reliefs et tectonique récente. Vuibert, Paris.

De Schacht, T., 2018. Unfinished business? Traces of apparent discontinuity in the Pasargadae countryside. In: Gondet, S., Haerinck, E. (Eds.), L'Orient est son jardin Hommage à Rémy Boucharlat. Peeters, Leuven, pp. 185-210.
De Schacht, T., De Dapper, M., Asadi, A., Ubelmann, U., Boucharlat, R., 2012.

Geoarchaeological study of the Achaemenid dam of sad-i didegan (fars, Iran). Géomorphologie 18 (1), 91-108. https://doi.org/10.4000/geomorphologie.9767.

Devillers, B., 2008. Holocene Morphogenesis of a Semi-arid Watershed and its Relation with Human Activities: the Gialias River (Cyprus). Archeopress, Oxford.

Djamali, M., de Beaulieu, J.-L., Miller, N.F., Andrieu-Ponel, V., Lak, R., Sadeddin, M., Akhani, H., Fazeli, H., 2009a. Vegetation history of the SE section of Zagros Mountains during the last five millennia; a pollen record from the Maharlou Lake, Fars Province, Iran. Veg. Hist. Archaeobotany 18, 123-136. https://doi.org/ 10.1007/s00334-008-0178-2.

Djamali, M., de Beaulieu, J.-L., Miller, N., Andrieu-Ponel, V., Berberian, M., Gandouin, E., Lahijani, H., Ponel, P., Salimian, M., Guiter, F., 2009b. A late Holocene pollen record from Lake Almalou in NW Iran: evidence for changing land-use in relation to some historical events during the last 3700 years. J. Archaeol. Sci. 36 (7), 1346-1375. https://doi.org/10.1016/j.jas.2009.01.022.

Djamali, M., Akhani, H., Andrieu-Ponel, V., Bracconnot, P., Brewer, S., de Beaulieu, J.-L., Fleitmann, D., Fleury, J., Gasse, F., Guibal, F., Jackson, S.T., Lézine, A.-M., Médail, M., Ponel, P., Roberts, N., Stevens, L., 2010. Indian Summer Monsoon variations could have affected the early Holocene woodland expansion in the Near East. Holocene 20 (5), 813-820. https://doi.org/10.1177/0959683610362813.

Djamali, M., Akhani, H., Khoshravesh, R., Andrieu-Ponel, V., Ponel, P., Brewer, S., 2011a. Application of the Global Bioclimatic Classification to Iran: implications for understanding the modern vegetation and biogeography. Ecol. Mediterr. 37 (1) 91-114. https://doi.org/10.3406/ecmed.2011.1350.

Djamali, M., Miller, N.F., Ramezani, E., Akhani, H., Andrieu-Ponel, V., de Beaulieu, J.-L., Berberian, M., Guibal, F., Lahijani, H., Lak, R., Ponel, P., 2011b. Notes on the arboricultural and agricultural practices in ancient Iran based on new pollen evidence. Paleorient 36 (2), 175-188. https://doi.org/10.3406/paleo.2010.5394.

Djamali, M., Jones, M.D., Migliore, J., Balatti, S., Fader, M., Contreras, D., Gondet, S., Hosseini, Z., Lahijani, H., Naderi-Beni, A., Shumilovskikh, L.S., Tengberg, M. Weeks, L., 2015. Olive cultivation in the heart of the Persian Achaemenid Empire: new insights to agricultural practices and environmental changes reflected in a late Holocene pollen record from Lake Parishan, SW Iran. Veg. Hist. Archaeobotany 25, 255-269. https://doi.org/10.1007/s00334-015-0545-8.

Djamali, M., Gondet, S., Ashjari, J., Aubert, C., Brisset, E., Longerey, J., Marriner, N., Mashkour, M., Millet, N.F., Naderi-Beni, A., Pourkerman, M., Rashidian, E., Rigot, J.B., Shidrang, S., Thiéry, A., Gandouin, E., 2018. Karstic-spring wetlands of the Persepolis Basin, SW Iran: unique sediment archives of Holocene change and human impact. Can. J. Earth Sci. 55 (10), 1158-1172. https://doi.org/10.1139/cjes-20180065.

English, P.W., 1998. Qanats and lifeworlds in Iranian plateau villages. Yale F\&ES Bulletin 103, 187-205. https://elischolar.library.yale.edu/cgi/viewcontent.cgi?article=11 $03 \&$ context $=$ yale fes

Fattahi, M., 2015. OSL dating of the Miam Qanat (KĀRIZ) system in NE Iran. J. Archaeol. Sci. 59, 54-63. https://doi.org/10.1016/j.jas.2015.04.006.

Faust, D., Wolf, D., 2017. Interpreting drivers of change in fluvial archives of the Western Mediterranean - a critical view. Earth-Sci. Rev. 174, 53-83. https://doi.org/ 10.1016/j.earscirev.2017.09.011.

Fontugne, M., Reyss, F.M., Hatté, J.L., Pirazzoli, P.A., Haghipou, r A., 1997. Global sea level changes as indicated by ${ }^{14} \mathrm{C}$ and ${ }^{230} \mathrm{Thr} /{ }^{234} \mathrm{U}$ dating of marine terraces in the Persian Gulf and along the Makran coast Iran. In: Meco, J., Petit-Maire, N. (Eds.), Climates of the Past - Proc. Of the CLIP Meeting. Universidad de Las Palmas de Gran Canaria, Las Palmas, pp. 79-87.

Fouache, E., 1999. L'alluvionnement historique en Grèce occidentale et au Péloponnèse. Géomorphologie, Archéologie, Histoire. Ecole française d'Athènes, Athènes.

Galbraith, R.F., Green, P.F., 1990. Estimating the component ages in a finite mixture. Int. J. Radiat. Appl. Instr. Part D 17 (3), 196-206. https://doi.org/10.1016/1359-0189 (90)90035-V.

Galbraith, R.F., Roberts, R.G., Laslett, G.M., Yoshida, H., Olley, J.M., 1999. Optical dating of single and multiple grains of quartz from Jinmium rock shelter, northern Australia: part I, experimental design and statistical models. Archaeometry 41, 339-364. https://doi.org/10.1111/j.1475-4754.1999.tb00987.x.

Gillmore, G.K., Stevens, T., Buylaert, J.P., Coningham, R.A.E., Batt, C., Fazeli Nashli, H., Young, R., Maghsoudi, M., 2011. Geoarchaeology and the value of multidisciplinary palaeoenvironmental approaches: a case study from the Tehran Plain, Iran. J. Geol. Soc. London 352, 49-67. https://doi.org/10.1144/SP352.

Gondet, S., Mohammadkhani, K., Farjamirad, M., Ibnoerrida, N., Zare-Kordshouli, F., Karami, H.R., Laisney, D., 2018a. Field report on the 2015 current archaeological works of the joint Iran-French project on Pasargadae and its territory. Iranian Heritage Studies 1 (1), 60-87. http://scj.sbu.ac.ir/index.php/IJIHS/article/view/ 29128.

Gondet, S., Mohammadkhani, K., Chambrade, M-I., Djamali, M., Farjamirad, M. Ibnoerrida, N., Rigot, J.-B., 2021. Approaching past landscape management in the field. Pluridisciplinary and multiscalar studies in the Pasargadae Region (Fars Province, Iran). In: Balatti, S., Wiesehöfer, J., Klinkott, H. (Eds.), Paleopersepolis: Environement, Landscape and Society in Ancient Fars. Franz Steiner Verlag, Stuttgart, pp. 95-119.

Gondet, S., Mohammadkhani, K., Djamali, M., Farjamirad, M., Gopnik, H., Ibnoerrida, N., Laisney, D., Notter-Truxa, F., Rigot, J.-B., Ubelmann, Y., 2018b. Field report on the 2016 archaeological works of the joint Iran-French project on Pasargadae and its surrounding territory. Iranian Heritage Studies 1 (2), 1-22. http://scj.sbu.ac.ir/index.php/IJIHS/article/view/29654.

Graf, W.L., 1988. Fluvial Process in Dryland Rivers. Springer Verlag, Berlin.

Gurjazkaite, K., Routh, J., Djamali, M., Vaezi, A., Poher, Y., Naderi-Beni, A., Tavakoli, V., Kyln, H., 2018. Vegetation history and human-environment interactions through the 
late Holocene in Konar Sandal, SE Iran. Quat. Sci. Rev. 194, 143-155. https://doi. org/10.1016/j.quascirev.2018.06.026.

Hammer, E., 2019. The city and landscape of Ur: an aerial, satellite, and ground reassessment. Iraq 81, 173-206. https://doi.org/10.1017/irq.2019.7.

Hamzeh, M.A., Mahmoudy-Gharaie, M.H., Alizadeh-Lahijani, H., Moussavi-Harami, R., Djamali, M., Naderi-Beni, A., 2016. Paleolimnology of Lake Hamoun (E Iran): implication for past climate changes and possible impacts on human settlements. Palaios 31 (12), 616-629. https://doi.org/10.2110/palo.2016.055.

Helwing, B., Makki, M., Seyedin, M., 2010. Prehistoric settlement patterns in Darre-ye Bolaghi, Fars, Iran: results of archaeological and geoarchaeological fieldwork. In: Matthiae, P., Pinnock, F., Nigro, L., Marchetti, N., Romano, L. (Eds.), Proceedings of the 6th International Congress on the Archaeology of the Ancient Near East. Harrassowitz, Wiesbaden, pp. 233-247.

Helwing, B., Seyedin, M., 2018. Achaemenid occupation in Tang-e Bolaghi. Some thoughts based on work at site TB 73 and beyond. In: Gondet, S., Haerinck, E. (Eds.), L'Orient est son jardin - Hommage à Rémy Boucharlat. Peeters, Leuven, pp. 225-236.

Henkelman, W.F.M., 2013. Administrative realities: the Persepolis archives and the archaeology of the Achaemenid heartland. In: Potts, D.T. (Ed.), The Oxford Handbook of Ancient Iran. Oxford University Press, Oxford, pp. 528-546.

Henkelman, W.F.M., 2017. Imperial signature and imperial paradigm: Achaemenid administrative structure and system across and beyond the Iranian plateau. In: Jacobs, B., Henkelman, W.F.M., Stolper, M. (Eds.), Die Verwaltung im Achämenidenreich - Imperiale Muster und Strukturen/Administration in the Achaemenid Empire - Tracing the Imperial Signature. Harrassowitz, Wiesbaden, pp. 45-256.

Huckleberry, G., Hayashida, F., Johnson, J., 2012. New insights into the evolution of an intervalley prehistoric irrigation canal system, North Coastal Peru. Geoarchaeology 27 (6), 492-520. https://doi.org/10.1002/gea.21420.

Jones, M.D., Roberts, C.N., 2008. Interpreting lake isotope records of Holocene environmental change in the Eastern Mediterranean. Quat. Int. 181 (1), 32-38. https://doi.org/10.1016/j.quaint.2007.01.012.

Jones, M.D., Djamali, M., Holmes, J., Weeks, L., Leng, M.J., Lashkari, A., Alamdari, K., Noorollahi, A., Thomas, L., Metcalfe, S.E., 2015. Human impact on the hydroenvironment of lake parishan, SW Iran, through the late Holocene. Holocene 25 (10), 1651-1661. https://doi.org/10.1177/0959683615594242.

Jones, M.D., Abu-Jaber, N., AlShdaifat, A., Baird, D., Cook, B.I., Cuthbert, M.O., Dean, J. R., Djamali, M., Eastwood, W., Fleitmann, D., Haywood, A., Kwiecien, O., Larsen, J., Maher, L.A., Metcalfe, S.E., Parker, A., Petrie, C.A., Primmer, N., Richter, T., Roberts, N., Roe, J., Tindall, J.C., Ünal-İmer, E., Weeks, L., 2019. 20,000 years of societal vulnerability and adaptation to climate change in southwest Asia. WIREs Water 6, e1330. https://doi.org/10.1002/wat2.1330.

Kehl, M., 2009. Quaternary climate change in Iran - the state of knowledge. Erdkunde 63 (1), 1-17. https://doi.org/10.3112/erdkunde.2009.01.01.

Kehl, M., Frechen, M., Skowronek, A., 2005. Paleosols derived from loess and loess-like sediments in the basin of Persepolis, Southern Iran. Quat. Int. 140-141, 135-149. https://doi.org/10.1016/j.quaint.2005.05.007.

Kehl, M., Frechen, M., Skowronek, A., 2009. Nature and age of Late Quaternary basin fill deposits in the basin of Persepolis/Southern Iran. Quat. Int. 196 (1-2), 57-70. https://doi.org/10.1016/j.quaint.2008.06.007.

Kleiss, W., 1988. Achaemenidische staudämme in fars. Archäol. Mitt. Iran Turan 21, 63-68.

Kleiss, W., 1991. Wasserschutzdämme und Kanalbauten in der Umgebung von Pasargadae. Archäol. Mitt. Iran Turan 25, 23-30.

Lespez, L., 2007. Dynamiques holocènes de systèmes fluviaux en Grèce du Nord : une approche comparative et multiscalaire des interactions entre Nature et Société. Géomorphologie 13 (1), 49-66. https://doi.org/10.4000/geomorphologie.669.

Manuel, M., Lightfoot, D., Fattahi, M., 2018. The sustainability of ancient water control techniques in Iran: an overview. Wat. Hist. 10, 13-30. https://doi.org/10.1007/ s12685-017-0200-7.

Mayewski, P.A., Rohling, E.E., Stager, J.C., Maasch, K.A., Meeker, L.D., Meyerson, E.A., Gasse, F., Kreveld, S. Van, Holmgren, K., Lee-thorp, J., Rosqvist, G., Rack, F., Staubwasser, M., Schneider, R.R., Steig, E.J., 2004. Holocene climate variability. Quat. Res. 62 (3), 243-255. https://doi.org/10.1016/j.yqres.2004.07.001.

Nadji, M., 1997. Rerouting of the Kur river from the Zagros region into the Persian gulf a proposed solution to the problem of salinization in the Persepolis basin, Iran. Z. Angew. Geol. 43, 171-178.

Nicol, M.B., 1970. Rescue Excavations Near Dorudzan, vol. 20. East \& West, pp. 245-285. https://www.jstor.org/stable/29755543.

Obaid, A.K., Allen, M.B., 2019. Landscape expressions of tectonics in the Zagros fold-andthrust belt. Tectonophysics 766, 20-30. https://doi.org/10.1016/j. tecto. 2019.05.024.

Orengo, H.A., Palet, J.M., 2016. Introduction. Archaeomorphology as landscape archaeology: new approaches and perspectives. In: Burgers, G.-J., et al. (Eds.), Multi, Inter- and Transdisciplinary Research in Landscape Archaeology. Vrije Universiteit Amsterdam, Amsterdam, pp. 1-5. In: http://lac2014proceedings.nl/article/v iew/37/13.

Powell, D.M., Brazier, R., Parsons, A., Wainwright, J., Nichols, M., 2007. Sediment transfer and storage in dryland headwater streams. Geomorphology 88 (1-2), 152-166. https://doi.org/10.1016/j.geomorph.2006.11.001.

Purdue, L., 2013. Dynamiques alluviales et adaptations aux contraintes hydroclimatiques dans le sud-ouest américain au cours des deux derniers millénaires (Phoenix, Arizona). Géomorphologie19 3, 243-264. https://doi.org/10.4000/ geomorphologie.10272.
Ramsey, L.A., Walkerw, R.T., Jackson, J., 2008. Fold evolution and drainage development in the Zagros mountains of Fars province, SE Iran. Basin Res. 20 (1) 23-48. https://doi.org/10.1111/j.1365-2117.2007.00342.x.

Rashidi, Z., Sohbati, R., Karimi, A., Farpoor, M.H., Khormali, F., Thompson, W., Murray, A., 2019. Constraining the timing of palaeosol development in Iranian arid environments using OSL dating. Quat. Geochronol. 92-100. https://doi.org/ 10.1016/j.quageo.2018.04.006.

Rigot, J.-B., 2010. Dynamique de la rivière Poulvar et morphogenèse de la plaine de Tang-i Bulaghi (Fars, Iran) à l'Holocène. Premiers résultats. Géomorphologie 16 (1), 57-72. https://doi.org/10.4000/geomorphologie.7813.

Roberts, N., 2002. Did prehistoric landscape management retard the post-glacial spread of woodland in Southwest Asia? Antiquity 76 (294), 1002-1010. https://doi.org/ 10.1017/S0003598X0009181X.

Saeidi Ghavi Andam, S., Djamali, M., Nelle, O., Naderi Beni, M., Haghighifard, M., Brisset, E., Poschlod, P., 2020. Vegetation history of Maharlou Lake basin (SW Iran) with special reference to Achaemenid period (550-330 B.C.). Veg. Hist. Archaeobotany 1-16. https://doi.org/10.1007/s00334-020-00810-1.

Safaierad, R., Mohtadi, M., Zolitschka, B., Yokoyama, Y., Vogt, C., Schefuß, E., 2020. Elevated dust depositions in West Asia linked to ocean-atmosphere shifts during North Atlantic cold events. Proc. Natl. Acad. Sci. Unit. States Am. 117, 18272-18277. https://doi.org/10.1073/pnas.2004071117.

Sharifi, A., Pourmand, A., Canel, E.A., Ferer-Tyler, E., Peterson, L.C., Aichner, B., Feakins, S.J., Daryaee, T., Djamali, M., Naderi Beni, A., Lahijani, H.A.K., Swart, P.K., 2015. Abrupt climate variability since the last deglaciation based on a highresolution, multi-proxy peat record from NW Iran: the hand that rocked the Cradle of Civilization? Quat. Sci. Rev. 123, 215-230. https://doi.org/10.1016/j. quascirev.2015.07.006.

Sharifi, A., Pourmand, A., Djamali, M., Peterson, L.C., Swart, P.K., Pulido Ávila, M.G., Esfahaninejad, M., Lahijani, H.A.K., 2019. The Rise and Demise of the World's Second Largest Hypersaline Lake: the Past Is Prologue to the Future of Urmia Lake. American Geophysical Union. Fall Meeting 2019, abstract \#PP51F-1439. https://ag u.confex.com/agu/fm19/meetingapp.cgi/Paper/501646.

Snyder, J.A., Wasylik, K., Fritz, S.C., Wright, H.E., 2001. Diatombased conductivity reconstruction and palaeoclimatic interpretation of a 40-ka record from Lake Zeribar, Iran. Holocene 11 (6), 737-745. https://doi.org/10.1191/ 09596830195753.

Stevens, L.R., Wright Jr., H.E., Ito, E., 2001. Proposed changes in seasonality of climate during the late-glacial and Holocene at Lake zeribar, Iran. Holocene 11, 747-756. https://doi.org/10.1191/09596830195762.

Stevens, L.R., Ito, E., Schwalb, A., Wright Jr., H.E., 2006. Timing of atmospheric precipitation in the Zagros mountains inferred from a multi-proxy record from Lake Mirabad, Iran. Quat. Res. 66 (3), 494-500. https://doi.org/10.1016/j. yqres.2006.06.008.

Stronach, D., 1978. Pasargadae: a Report on the Excavations Conducted by the British Institute of Persian Studies from 1961 to 1963. Clarendon Press, Oxford.

Sumner, W.M., 1986. Achaemenid settlement in the Persepolis plain. Am. J. Archaeol. 90 (1), 3-31. https://www.jstor.org/stable/505980.

Talebi, T., Ramezani, E., Djamali, M., Lahijani, H.A.K., Naqinezhad, A., Alizadeh, K., Andrieu-Ponel, V., 2016. The Late-Holocene climate change, vegetation dynamics, lake-level changes and anthropogenic impacts in the Lake Urmia region, NW Iran. Quat. Int. 408 (Part A), 40-51. https://doi.org/10.1016/j.quaint.2015.11.070.

Tatar, M., Hatzfeld, D., Martinod, J., Walpersdorf, A., Ghafori-Ashtiany, M., Chéry, J., 2002. The present-day deformation of the central Zagros from GPS measurements. Geophys. Res. Lett. 29 (19), 1927. https://doi.org/10.1029/2002GL015427.

Thiel, C., Buylaert, J.-P., Murray, A.S., Terhorst, B., Hofer, I., Tsukamoto, S., Frechen, M., 2011. Luminescence dating of the Stratzing loess profile (Austria) - testing the potential of an elevated temperature post-IR IRSL protocol. Quat. Int. 234 (1-2), 23-31. https://doi.org/10.1016/j.quaint.2010.05.018.

Thomas, D.S.G., Bateman, M.D., Mehrshahi, D., O'hara, S.L., 1997. Development and environmental significance of an eolian sand ramp of Last-Glacial Age, Central Iran. Quat. Res. 48 (2), 155-161. https://doi.org/10.1006/qres.1997.1923.

Tooth, S., 2000. Process, form and change in dryland rivers: a review of recent research. Earth-Sci. Rev. 51 (1-4), 67-107. https://doi.org/10.1016/S0012-8252(00)000143.

Tsuneki, A., Zeidi, M., 2008. Tang-e Bolaghi. The Iran-Japan Archaeological Project for the Sivand Dam Salvage Area. Iranian Center for Archaeological ResearchUniversity of Tsubuka, Tehran-Tsukuba.

Uchupi, E., Swift, S.A., Ross, D.A., 1999. Late Quaternary stratigraphy, Paleoclimate and neotectonism of the Persian-Arabian/Gulf region. Mar. Geol. 160 (1-2), 1-23. https://doi.org/10.1016/S0025-3227(99)00011-0.

Vaezi, A., Ghazban, F., Tavakoli, V., Routh, J., Beni, A.N., Bianchi, T.S., Curtis, J.H., Kylin, H., 2019. A Late Pleistocene-Holocene multi-proxy record of climate variability in the Jazmurian playa, southeastern Iran. Palaeogeogr. Palaeoclimatol. Palaeoecol. 514, 754-767. https://doi.org/10.1016/j.palaeo.2018.09.026.

Vandenberghe, J., 1995. Timescales, climate and river development. Quat. Sci. Rev. 14 (6), 631-638. https://doi.org/10.1016/0277-3791(95)00043-O.

Van Zeist, W., Bottema, S., 1977. Palynological investigations in western Iran. Palaeohistoria 19, 19-85. https://ugp.rug.nl/Palaeohistoria/article/view/25018/ 22478.

Vernant, P., Nilforoushan, F., Hatzfeld, D., Abbassi, M.R., Vigny, C., Masson, F., Nankali, H., Martinod, J., Ashtiani, A., Bayer, R., Tavakoli, F., Chéry, J., 2004. Present-day crustal deformation and plate kinematics in theMiddle East constrained by GPS measurements in Iran and northern Oman. Geophys. J. Int. 157 (1), 381-398. https://doi.org/10.1111/j.1365-246X.2004.02222.x. 
Vidale, M., 2018. Irrigation and canals in ancient Iran. Resurrecting wittfogel? In: Callieri, P., Rossi, A.V. (Eds.), Civiltà Dell'Iran - Passato Presente Futuro. Scienze Lettere, Rome, pp. 27-53.

Walker, R.T., Fattahi, M., 2011. A framework of Holocene and Late Pleistocene environmental change in eastern Iran inferred from the dating of periods of alluvial fan abandonment, river terracing, and lake deposition. Quat. Sci. Rev. 30 (9-10), 1256-1271. https://doi.org/10.1016/j.quascirev.2011.03.004.

Wasylikowa, K., Van Zeist, W., Wright Jr., H.E., Stevens, L., Witkowski, A., Walanus, A., Hutorowicz, A., Alexandrowicz, S.W., Langer, J.J., 2008. The Lake Zeribar palaeoecology: a synthesis. In: Wasylikowa, K., Witkowski, A. (Eds.), The Palaeoecology of Lake Zeribar and Surrounding Areas, Western Iran, during the Las 48,000 Years. A.R.G. Gantner Verlag K.G., Ruggel, pp. 303-321.

Wei, H., Wang, L., Azarmdel, H., Khormali, F., Frechen, M., Li, G., Chen, F., 2021. Quartz OSL dating of loess deposits since the late glacial in the Southeast of Caspian Sea. Quat. Int. 39-47. https://doi.org/10.1016/j.quaint.2020.04.042.

Wilkinson, T.J., 1999. Holocene Valley fills of Southern Turkey and Northwestern Syria: recent geoarchaeological contribution. Quat. Sci. Rev. 18 (4-5), 555-571. https:// doi.org/10.1016/S0277-3791(98)00097-3.
Wilkinson, T.J., 2003. Archaeological Landscapes of the Near East. University of Arizona Press, Tucson.

Wilkinson, T.J., Gillmore, G., Boucharlat, R., Ertsen, M.W., De Schacht, T., Magee, P., Rezakhani, K., Kennet, D., 2012. From human niche construction to imperial power: long-term trends in ancient Iranian water systems. Wat. Hist. 4, 155-176. https:// doi.org/10.1007/s12685-012-0056-9.

Wintle, A., Murray, A.S., 2006. A review of quartz optically stimulated luminescence characteristics and their relevance in single-aliquot regeneration dating protocols. Radiat. Meas. 41 (4), 369-391. https://doi.org/10.1016/j.radmeas.2005.11.001.

Wright Jr., H.E., Ammann, B., Stefanova, I., Atanassova, J., Margalitadze, N., Wick, L. Blyakharchuk, T., 2003. Late-glacial and early-Holocene dry climates from the Balkan Peninsula to southern Siberia. In: Tonkov, S. (Ed.), Aspects of Palynology and Palaeoecology, Festschrift in Honour of Elissaveta Bozilova. Pensoft, Sofia-Moscow, pp. 127-136.

Yamauchi, K., Nishiyama, S., 2008. Archaeological survey in the Bolaghi valley and its vicinity, In: Tsuneki, A, Zeidi, M. (Eds.), Tang-e Bolaghi. The Iran-Japan Archaeological Project for the Sivand Dam Salvage Area. Iranian Center for Archaeological Research - University of Tsubuka, Tehran -Tsukuba, pp. 169-252. 